\title{
The 1906 Dobrá Voda Earthquake ( $M=5.7$ ) at the Vienna Basin Transfer Fault: evaluation of the ESI2007 intensity and analysis of the aftershock sequence
}

\author{
Asma NASIR ${ }^{(1)}$, Esther HINTERSBERGER ${ }^{(2)}$, Kurt DECKER ${ }^{(1)}$ \\ ${ }^{(1)}$ Department of Geodynamics and Sedimentology, Center of Earth Sciences, University of Vienna, Althanstrasse 14,A- 1090 Vienna, Austria; \\ ${ }^{(2)}$ Geological Survey of Austria (GBA), Neulinggasse 38, A-1030 Vienna, Austria; \\ *) Corresponding Author, asma.nasir@univie.ac.at
}

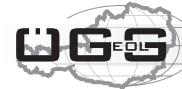

KEYWORDS 1906 Dobrá Voda earthquake; Vienna Basin; aftershock; environmental intensity

\begin{abstract}
Aftershock identification plays an important role in the assessment and characterization of large earthquakes. Especially, the length of the aftershock sequence is an important aspect of declustering earthquake catalogues and therefore impacts the frequency of earthquakes in a certain region, which is important for future seismic hazard assessment. However, in intraplate regions with low deformation rates and low to moderate seismicity, it is still questionable if aftershocks after a major event may continue for much longer time. In this study, we use one of the earliest instrumentally recorded earthquakes, the 1906 Dobrá Voda earthquake ( $\left.\mathrm{Ms} / \mathrm{I}_{\max }=5.7 / \mathrm{VIII}-\mathrm{IX}\right)$, to compare different approaches of aftershock determination and their suitability for understanding the recorded earthquake sequence. The Dobrá Voda segment of the Vienna Basin Transfer Fault System is one of the seismically most active zones in Slovakia with the 1906 earthquake as the strongest recorded earthquake. We first assess the epicentral intensity of the earthquake according to the Environmental Intensity Scale (ESI2007) using contemporary descriptions of earthquake effects. This additional information leads to constrain the maximal intensity to IESI2007=IX. This result agrees well with first the assessment of Imax in 1907 and indicates the reliability of this intensity data. In the second step, earthquake data are plotted for two spatial windows extending $13 \mathrm{~km}$ and $26 \mathrm{~km}$ from the epicenter of the mainshock, respectively. Despite uncertainties regarding the completeness of data due to war times and lack of nearby seismic stations, the overall temporal evolution of seismicity can apparently not be described as an Omori-type aftershock sequence following the event in 1906. Instead, earthquake occurrence within $13 \mathrm{~km}$ of the mainshock shows elevated earthquake activity right after the 1906 event that only decays to a lower level of activity within decades after the mainshock. The decline of seismicity therefore occurs over time scales which are much longer than those predicted by the Omori relation. We conclude that today's seismic activity may still be affected by the 1906 earthquake.
\end{abstract}

\section{Introduction}

\subsection{Background and objectives}

The 1906 Dobrá Voda $\left(\mathrm{M} / \mathrm{I}_{\max }=5.7 / \mathrm{VIII}-\mathrm{IX}\right)$ earthquake is the strongest historically recorded earthquake along the Vienna Basin Transfer Fault System. It occurred in the border region between Austria, Slovakia, and Czech Republic during the transition from the macroseismic/ historical recording of seismic events to instrumental recording (Réthly, 1907) (Fig. 1). The installation of seismographs and the systematic recording of macroseismic observations in the former Austro-Hungarian Empire were initiated after the 1895 Ljubljana/Laibach earthquake (Süss, 1897). The 1906 Dobrá Voda earthquake and its numerous aftershocks therefore received much scientific attention (Réthly, 1907; Kárnik, 1968; Zsíros, 2005) and instrumentally recorded earthquakes are available covering the aftermath of the mainshock until today (ACORN, 2004; Fojtikova et al., 2010).

Large earthquakes are typically followed by aftershock activity that decays hyperbolically with time after the mainshock, following the empirical Omori's Law (Ogata, 1983). The end of the aftershock activity is difficult to identify precisely, because its definition depends on several parameters, such as the area treated as the aftershock zone and the level of background seismicity before the mainshock (Stein and Liu, 2009). Therefore, one common and practical way of automatic aftershock detection is the usage of temporal and spatial windows with the window length and size depending on the magnitude of the mainshock (e.g. Gardner and Knopoff, 1974; Wells and Coppersmith, 1994). However, in diffuse plate boundaries such as the North American Basin-and-Range, or in intraplate regions with low to moderate seismicity distributed over a wide area such as Central Europe or China outside the Tibetan Plateau, the question has risen whether aftershock sequences can continue for a much longer time than predicted by the above-mentioned methods (Stein and Liu, 2009). The ongoing seismicity in the Dobrá Voda area therefore raises the question whether earthquakes today may still be related to the 1906 Dobrá Voda earthquake or if the recent seismicity observed 
within the region corresponds to a level that can be interpreted as 'normal' background seismicity.

Basic information about the 1906 Dobrá Voda earthquake and its aftershocks has been obtained from the ACORN catalogue (ACORN, 2004). In addition to the catalogue data, detailed contemporaneous documentation of the damages caused by the 1906 earthquake is available that includes descriptions of earthquake effects on the natural environment (Réthly, 1907). We use these descriptions to determine the macroseismic intensities based on the Environmental Seismicity Intensity (ESI) scale (Michetti et al., 2007).

Our scope in this study is two-fold: 1) By incorporating environmental effects of the earthquake, we check if this additional information changes the assessment of the Imax (Maximum Intensity), and the assigned intensity for the Dobrá Voda earthquake. 2) By investigating the seismicity on the Dobrá Voda segment for the past 150 years, we explore whether the observed seismicity today could be still be related to the 1906 earthquake, or merely reflects background seismicity. To achieve this, we also consider how the number of recorded earthquakes is related to the development of the seismic network in the area.

\subsection{Seismotectonic Setting of the Vienna Basin}

The Vienna Basin Transfer Fault System (VBTF) is a seismically active sinistral fault between the Eastern Alps, the Western Carpathians and the Pannonian Basin (Fig. 1). Active seismogenic deformation along the fault is indicated by moderate historical and instrumentally recorded seismicity in a NE-striking zone paralleling the fault between the Alps (Mur-Mürz Fault System) and the Vienna Basin in Austria, and the Malé Karpaty Mountains (Little Carpathians) and Váh Valley in Slovakia (e.g., Lenhardt et al., 2007; Hammerl and Lenhardt, 2013). The hypocentre depths of the recorded earthquakes are generally between 3 and $12 \mathrm{~km}$. The earliest earthquake reported from the Vienna Basin occurred in 1283 (Wiener Neustadt, $\mathrm{I}_{0}=\mathrm{V}$; Hammerl and Lenhardt, 2013). Moderate to relatively high seismicity occurs in the southern Vienna Basin (including the 1927 Schwadorf earthquake $\mathrm{M} / \mathrm{I}_{0}=5.2 / \mathrm{VIII}$ ) and the Dobrá Voda segment at the northern end of the Vienna Basin (1906 Dobrá Voda earthquake). In contrast, no significant earthquakes have been observed in the central Vienna Basin in the last four centuries (Hinsch and Decker, 2003; 2011). Comparison of seismic slip calculated from seismic moment summation shows significant differences between the segments of the VBTF. Seismic slip of more than $0.7 \mathrm{~mm} / \mathrm{a}$ at the seismically most active segments (Schwadorf and Dobrá Voda fault segments) contrasts with slip rates close to zero at the Lassee fault (Hinsch and Decker, 2003, 2008; Bus et al., 2009). All segments, however, show marked slip deficits for the last century when comparing seismic slip rates with geodetic data and geologically derived slip rates of about 1-2 mm/a (Decker et al., 2005; Grenerczy, 2002; Grenerczy et al., 2000).

\subsection{The Dobrá Voda segment}

The Dobrá Voda segment is one of the seismically most active zones in Slovakia (Fig. 1). It is located at the transition zone between the Vienna Basin and the Western Carpathians (Šefara et al., 1998; Lenhardt et al., 2007), specifically, at the Brezovské Karpaty Mountains north of the Malé Karpaty Mountains. The dominant structures of the area are ENE-WSW trending faults forming a transpressional ridge. This segment of the VBTF is interpreted as a restraining bend (Hinsch and Decker, 2011). The sinistral Brezová fault zone forms the northern margin of the Brezová elevation, while its southern border with the Dobrá Voda depression is represented by the distinctive sinistral Dobrá Voda fault zone (Marko et al., 1991). The faults separate the uplifted Mesozoic Brezová Block from Early Miocene molasses sediments to the $\mathrm{N}$ and $\mathrm{S}$. located between two sinistral fault zones, the Brezová Block has been interpreted as a positive flower structure, which formed at the VBTF during the Miocene (Marko et al., 1991; Beidinger and Decker, 2011). Convergent sinistral strike-slip faulting along the fault segment is confirmed by fault plane mechanisms (Fojtikova et al., 2010). The predominant focal mechanisms of the small earthquakes $(\mathrm{M}=1.2-3.4)$ are compatible with oblique-reverse left lateral strike slip on WSW-ENE striking faults (Fojtikova et al., 2010). This data is consistent with the interpretation that earthquakes occur along the ENE-WSW trending restraining bend.

The orientation of the present-day tectonic stress calculated from focal mechanisms and other stress measurements in the Western Carpathians region and adjacent areas are summarized in the world stress map (Müller et al., 1992; Heidbach et al., 2008). The area lies in the transition zone between the Western Carpathians and the eastern Alps and is characterized a complicated stress pattern (Drimmel and Trapp, 1982; Jarosinski, 1998; Reinecker, 2000; Kováč et al., 2002; Jarosinski, 2005). The mapped maximum horizontal compression in the Dobrá Voda area has an azimuth of 30-40 ${ }^{\circ} \mathrm{NE}$ and lies along the strike of the Male Karpaty Mts. (Fojtikova et al. 2010).

\section{Data}

\subsection{Seismicity data}

Information about the mainshock and all reported aftershocks of the Dobrá Voda 1906 earthquake are listed in the ACORN catalogue. The ACORN catalogue contains events with $\mathrm{I}_{0}=\mathrm{II}-\mathrm{IX}$, covering a rectangular area between $47.5^{\circ}$ and $49.8^{\circ}$ in latitude and $13.0^{\circ}$ to $19.0^{\circ}$ in longitude in the Czech Republic, Slovakia, Hungary, and Austria encompassing the Eastern Alps, Western Carpathians and the Bohemian Massif (Lenhardt et al., 2007). The data set includes 1968 earthquakes from the time between 1267 AD and 2004 AD. The "observation threshold" for earthquake data, i.e., the minimum magnitude/epicentral intensity for inclusion in the ACORN catalogue is $\mathrm{M} / \mathrm{I}_{0}=2.5 / \mathrm{III}$. Near the village of Dobrá Voda, the oldest earthquake listed in the catalogue is from $1515\left(\mathrm{M} / \mathrm{I}_{0}=5 / \mathrm{VII}\right)$. The oldest known 


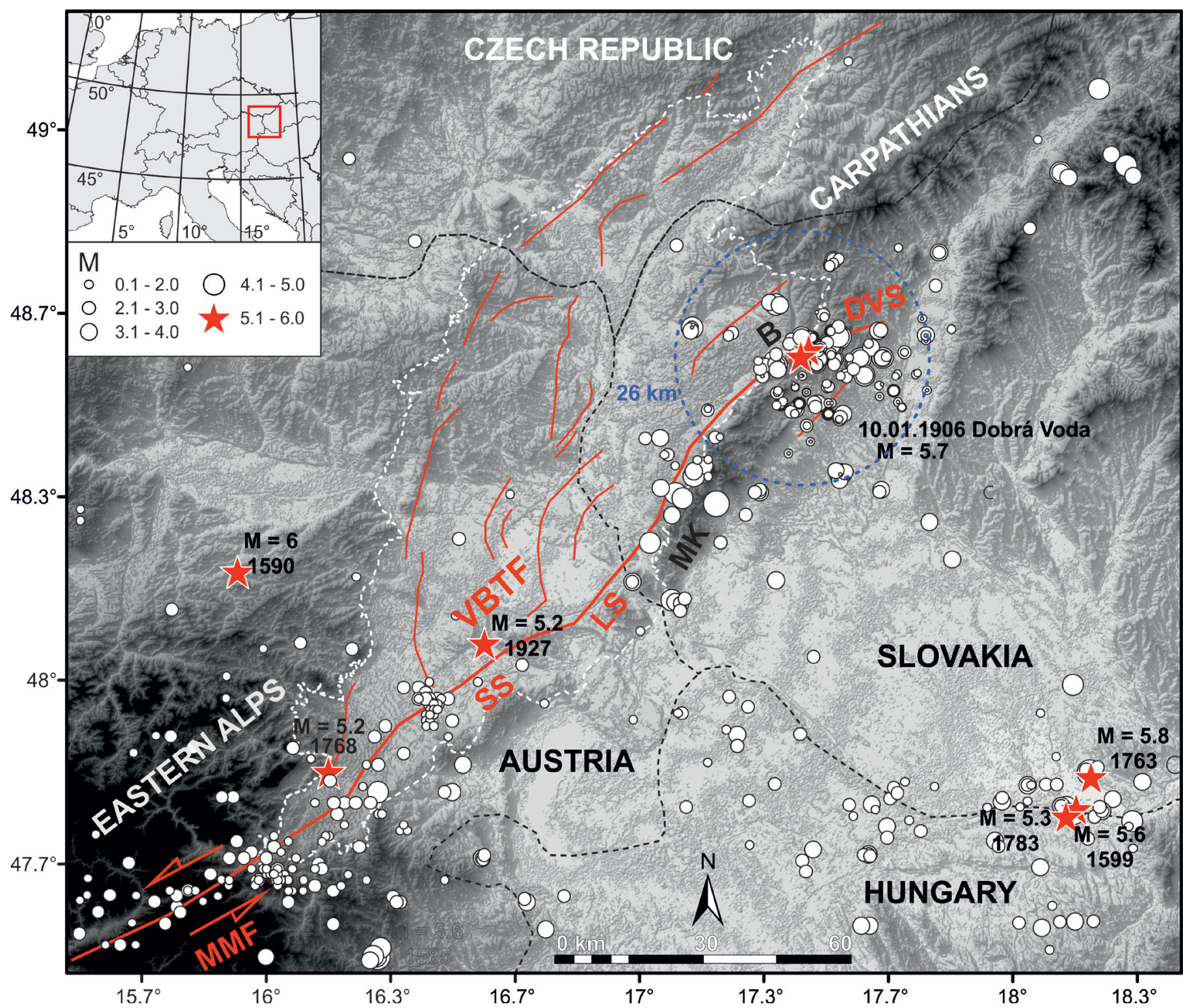

Fig. 1: Tectonic setting and earthquake scattered plot covering areas in Czech Republic, Slovakia, Hungary, and Austria (ACORN, 2004). Black stars show earthquakes with magnitudes larger than 5, red star indicates the location of the Dobrá Voda Earthquake. Blue circle marks the $26 \mathrm{~km}$ radius from the 16.01.1906 Dobrá Voda mainshock. Inset shows the location of the figure in Europe. MMF (Mur-Mürz-Fault); VBTF (Vienna Basin Transfer Fault); Fault segments of the VBTF: SS (Schwadorf); LS (Lassee) DVS (Dobrá Voda); MK (Male Karpaty mountains); B (Brezovské Karpaty mountains).

earthquakes along the VBTF occurred in 1267 (Kindberg/ Styria, $\mathrm{M} / \mathrm{I}_{0}=5.4 / \mathrm{VIII}$ ) and 1283 (Wiener Neustadt, $\mathrm{I}_{0}=\mathrm{V}$; ACORN catalogue, 2004; Hammerl and Lenhardt, 2002).

The installation of the first seismographs in the former Austro-Hungarian empire commenced at the turn from the 19th to the 20th century as a consequence of the earthquake of Ljubljana (Hammerl and Lenhardt, 2013). The first seismographic station of the territory of Slovakia has been installed in 1902. However, until the early 1990's, only a few seismic stations existed in the area of interest (Lenhardt et al., 2007). The further development includes the first digital seismological station, which is in operation since 1990, and the modernisation of the network 20012004 (Csicskay et al., 2018). Today, the local seismic activity around the Dobrá Voda area is monitored by MKnet seismic network, installed in 1985, the Slovak National Seismic Network (Cipciar et al., 2002), and a micro displacement monitoring network (Briestenský et al., 2007).

\subsection{Documentation of the 1906 Dobrá Voda earth- quake}

The main resource for the documentation of the 1906 Dobrá Voda earthquake and resulting damages is a report by the Hungarian seismologist Réthly (1907). The damage to buildings and the reactions of the population to the earthquake was described in detail for 180 locations and used for assessment of the local intensities and epicentral intensity. Réthly (1907) used the 12-degree extended Forel-Mercalli intensity scale (Cancani, 1904) for his assessment, which is broadly comparable to the successional intensity scales including the European Macroseismic Scale (EMS-98, see Musson et al., 2010 for a detailed discussion). Réthly's (1907) I=IX isoseismal includes 12 intensity data points and about $390 \mathrm{~km}^{2}$. Réthly $(1907$, p. 60) further noted that the long axis of the I=IX isoseismal is oriented WSW-ENE (Fig. 2), which is parallel to the strike of the Dobrá Voda segment of the VBTF mapped by Beidinger and Decker (2011). 
The description of the earthquake effects of the mainshock on 10.01 .1906 and the largest aftershock on 16.01.1906 include also effects on the natural environment, clearly distinguishing between both earthquakes (Réthly, 1907). The environmental effects of the mainshock included temporary changes in well water level, drying out of springs and wells, changes in water chemistry and temperature, and the generation of new springs. Detailed description these occurrences are given in Tab. 1. In addition, mostly temporal effects on well water and sulphuric enrichment of spring waters were observed for the largest aftershock on 16.01.1906.

Recent EMS-based catalogues list the epicentral intensity of the Dobrá Voda mainshock as $I_{0}=$ VIII-IX (Grünthal et al., 2009; ACORN, 2004; Zsíros, 2005). Re-assessment based on intensity datapoints and isoseismals lead to focal depth estimates between $2.8 \mathrm{~km}$ and $6.7 \mathrm{~km}$ (Zsíros, 2005). For precision the strongest aftershock, Réthly (1907) notes a maximum intensity of $I_{0}=I X$ as well, although this intensity was only assessed at two locations. ACORN (2004) and Grünthal et al. (2009) assess the strongest aftershock with $\mathrm{I}_{0}=\mathrm{VII}-\mathrm{VIII}\left({ }^{\prime \prime} \mathrm{I}=7.5^{\prime \prime}\right)$. As one of the first instrumentally recorded earthquakes in the Austrian-Hungarian Empire, the magnitude of the Dobrá Voda earthquake was obtained from instrumentally recorded surface-waves. The resulting surface-wave magnitude of Ms = 5.7 (Réthly, 1907; Kárník, 1968; ACORN, 2004) corresponds to a moment magnitude $\mathrm{Mw}=5.8$ according to the empirical conversions by Scordilis (2006) and Kadirioglu and Kartal (2016).

\section{Assessment of the epicentral intensity based on the ESI}

\subsection{Contemporary description of relevant secondary earthquake effects}

Macroseismic intensity data points of Forel-Mercalli as well as for the EMS-98 are derived from effects of humans, objects and damage to buildings (Grünthal et al., 1998). The Environmental Seismic Intensity (ESI) scale (Michetti et al., 2007), however, focuses on environmental effects to determine intensity levels. The ESI is designed so that the intensity determined from natural effects matches the intensity derived from macroseismic observations as described in the EMS-98 (Grünthal, 1998). Here, we evaluate the descriptions of environmental effects provided by Réthly (1907) using the ESI scale for the mainshock and the strongest aftershock on 16.01.1906, and then compare the resultant intensity levels with intensity data points derived using the macroseismic Forel-Mercalli intensity scale (Fig. 2). The documented changes in hydrological conditions are important parameters for the ESI 2007 intensity evaluation.

For the mainshock on 10.01.1906, reported hydrologic anomalies include variations of spring discharge, well water levels, water turbidity, changes of water temperature, and sulphurous emissions (Tab. 1). Especially the abundance of the effects at Cerová can be assessed from the description "all but two wells fell dry" (Tab. 1, Fig. 2). In addition, the generation of a permanent sulphur spring is mentioned from the village Hradiste pod Vratnom. For the remaining villages, the hydrological effects are widespread, but mostly of temporal nature (Mühlmann et al., 2012).

In the Hungarian language part of the damage report, Réthly (1907) describes surface cracks that opened in the epicentral area. However, he visited the area only after the 16.01.1906 aftershock, so the features that he describes might also have been caused by the later earthquake, and not by the mainshock. One location is extensively documented by photographs. It was interpreted as being probably caused by water-saturated soil at the inclined surface that started to slide during the earthquake (Réthly, 1907). The cracks were thought to be caused by "the roughness of the subsurface". One crack is described as $33 \mathrm{~m}$ long with a $140 \mathrm{~cm}$ high scarp, an opening of 130$140 \mathrm{~cm}$ width and a depth of $80-110 \mathrm{~cm}$. Another crack close by was $14 \mathrm{~m}$ long, $40 \mathrm{~cm}$ wide and showed a height difference from $60 \mathrm{~cm}$ up to $110 \mathrm{~cm}$. Localized up to $3 \mathrm{~m}$ wide cracks were observed at several more places. In addition, local landslides were triggered by ground shaking near the village of Dobrá Voda. The total area affected by such effects is about $250 \mathrm{~km}^{2}$ (Tab. 2a, Fig. 2). Records of environmental effects for the aftershock on 16.01.1906 are restricted to four intensity datapoints (Tab. 1, Fig. 2b) with reports from Jablonica indicating the severest effects. The total area from which hydrological effects were reported is about $80 \mathrm{~km}^{2}$ (Tab. 2, Fig. 2b).

\subsection{Interpretation of secondary earthquake effects}

The size and length of the cracks described by Réthly (1907) and their occurrence in water-saturated soil helps identify them as typical secondary earthquake effects. The application of the ESI 2007 to the macroseismic report (Réthly, 1907) uses hydrological anomalies and slope movements, which are described in sufficient detail to allow assessing local intensities for five locations for the mainshock (10.01.1906) and four intensity data points for the aftershock on 16.01.1906 (Tab. 1). The locations from which secondary effects were reported define a minimum area of about $250 \mathrm{~km}^{2}$ supporting IESI-2007=VIII-IX (Tab. 2). Tab. 1 shows that most of the reported effects refer to hydrological anomalies, all of them being indicative for ESI intensity $\geq$ VII. Descriptions of turbid waters in wells in the villages of Bucovec and Trstín indicate that the effect was "common" at these sites leading to an assessment of IESI=IX (Tab. 2). For Cerová, "all except two" wells ran dry, including one well which remained dry until March 1906 possibly indicating a local intensity IESI-2007=X. The formation of a sulphur spring in Hradiste pod Vratnom also indicates a significant environmental impact of the earthquake. However, an intensity value cannot be assessed as the descriptions of the ESI 2007 intensities only refer to springs running dry and not to the formation of new springs.

For the aftershock on 16.01.1906, hydrologic anomalies were recorded from four locations leading to assessments 


\begin{tabular}{|c|c|c|c|c|c|c|}
\hline Location & Lat & Long & $\begin{array}{l}\text { Intensity } \\
\text { Forel-Mercalli }\end{array}$ & $\begin{array}{l}\text { Intensity } \\
\text { ESI } 2007\end{array}$ & $\begin{array}{l}\text { Original German description by } \\
\text { Réthly (1907) }\end{array}$ & English translation \\
\hline \multicolumn{7}{|l|}{ Precursory effects } \\
\hline Vrbové/Verbó/ & 48.622 & 17.724 & & & $\begin{array}{l}\text { "Am 8.1. in der Früh war in dem } 24 \mathrm{~m} \\
\text { tiefen Brunnen der staatlichen Schule } \\
\text { kein Wasser, Nachmittags um } 14 \text { Uhr } \\
\text { war schon wieder ein bisschen trübes } \\
\text { Wasser, während gegen } 17 \text { h der } \\
\text { Brunnen wie gewohnt mit Wasser } \\
\text { gefüllt war." }\end{array}$ & $\begin{array}{l}\text { "In the morning of January, } 8 \text { th, there } \\
\text { was no water in the } 24 \text { m deep well of } \\
\text { the school, at } 2 \text { pm there was some } \\
\text { muddy water, and at } 5 \text { pm, the well was } \\
\text { filled again with clear water as normal." }\end{array}$ \\
\hline \multicolumn{7}{|l|}{ Mainshock 10.01.1906 } \\
\hline Dobrá Voda/ Jókeö & 48.599 & 17.541 & IX & VIIIIX & $\begin{array}{l}\text { "Die Blava-Quelle nahm eine } \\
\text { rote Trübung an und klärte sich } \\
\text { erst } 4 \text { h später. An zwei Stellen in } \\
\text { der Umgebung von Jókeö gab es } \\
\text { Erdrutschungen, z.B. südwestlich an } \\
\text { einem Hang des Brezover Gebirges." } \\
\text { Etwa } 2400 \mathrm{~m}^{2} \text { große „Schichten- } \\
\text { rutschung ... auf sanft ansteigender } \\
\text { Lehne am Fusse des Kopec" nahe } \\
\text { Dobra Voda auf wassergesättigtem } \\
\text { Boden mit mehreren Spalten, } \\
80200 \mathrm{~cm} \text { tief, } 33 \text { m lang, } 60 \text { - } 110 \mathrm{~cm} \\
\text { Höhenunterschied. }\end{array}$ & $\begin{array}{l}\text { "Water of the Blava spring turned } \\
\text { turbid red and cleared only } 4 \text { hours } \\
\text { later. Landslides occurred at two } \\
\text { locations near Jókeö, e.g., to the SW at } \\
\text { a slope of the Breva Mountains." } \\
\text { c. } 2400 \mathrm{~m}^{2} \text { large slide in water } \\
\text { saturated soil near Dobra Voda with } \\
\text { cracks } 80-200 \mathrm{~cm} \text { deep, } 33 \mathrm{~m} \text { long } \\
\text { and } 60-110 \mathrm{~cm} \text { difference of elevation }\end{array}$ \\
\hline $\begin{array}{l}\text { Hradiste pod } \\
\text { Vratnom/ Hradist }\end{array}$ & 48.626 & 17.487 & IX & $?$ & $\begin{array}{l}\text { "Nach dem Erdbeben entstand eine } \\
\text { Schwefelquelle." Diese liegt ca. 5-6 km } \\
\text { vom angenommenen Epizentrum } \\
\text { entfernt. }\end{array}$ & $\begin{array}{l}\text { "A sulfur spring formed after the } \\
\text { earthquake" at a distance of about } \\
5-6 \mathrm{~km} \text { from the assumed epicenter. }\end{array}$ \\
\hline Bucovec/ Bukov & 48.700 & 17.496 & VIII & IX & „Das Brunnenwasser wurde trüb.” & $\begin{array}{l}\text { "Well water became turbid." } \\
\text { Wording suggests that the effect } \\
\text { applied to the wells in the village in } \\
\text { general indicting that it occurred } \\
\text { commonly. }\end{array}$ \\
\hline Trstín / Nádas & 48.527 & 17.463 & IX & IX & „Das Brunnenwasser wurde trüb.” & $\begin{array}{l}\text { "Well water became turbid." } \\
\text { Wording suggests that the effect } \\
\text { applied to the wells in the village in } \\
\text { general indicting that it occurred } \\
\text { commonly. }\end{array}$ \\
\hline Dechtice / Dejte & 48.547 & 17.594 & & $\geq \mathrm{VII}$ & $\begin{array}{l}\text { "Starkes Brausen, eine Schwefelquelle } \\
\text { floss 2-3 Tage lang reichlicher." }\end{array}$ & $\begin{array}{l}\text { "Laud booming, discharge of a sulfur } \\
\text { spring increased for 2-3 days." }\end{array}$ \\
\hline Cerová/ Czerova & 48.586 & 17.379 & IX & $\mathrm{x}$ & $\begin{array}{l}\text { „Alle Brunnen bis auf } 2 \text { waren } \\
\text { ausgetrocknet." } \\
\text { "Das Wasser der Brunnen im } \\
\text { Jagdschloss verschwindet völlig und } \\
\text { taucht erst im März wieder auf." }\end{array}$ & $\begin{array}{l}\text { "All wells but } 2 \text { fell dry." } \\
\text { "Water of the well in the hunting castle } \\
\text { disappeared, the well remained dry } \\
\text { until March." }\end{array}$ \\
\hline \multicolumn{7}{|l|}{ Aftershock 16.01.1906 } \\
\hline Dobrá Voda/ Jókeö & 48.599 & 17.541 & - & VIII-IX & $\begin{array}{l}\text { "In der Blava Quelle hob sich der } \\
\text { Wasserstand um } 6 \mathrm{~cm} \text {. Die schwächste } \\
\text { der drei Abzweigungen, die mittlere, } \\
\text { war sehr ergiebig. Nach dem Erdbeben } \\
\text { war das sonst klare Wasser rostfarben } \\
\text { und sehr heiß, } 5 \text { Tage später war es } \\
\text { wieder normal." }\end{array}$ & $\begin{array}{l}\text { "The water level of the Blava Increased } \\
\text { by } 6 \mathrm{~cm} \text {. The smallest outflowing } \\
\text { channel (the one in the middle) showed } \\
\text { high discharge. The outflowing water } \\
\text { was very hot, normal conditions re- } \\
\text { established after } 5 \text { days." }\end{array}$ \\
\hline Jablonica / Jablonic & 48.830 & 17.421 & - & IX & $\begin{array}{l}\text { "Das Brunnenwasser der gesamten } \\
\text { Umgebung war getrübt." }\end{array}$ & $\begin{array}{l}\text { "Well water of the entire surroundings } \\
\text { was turbid." }\end{array}$ \\
\hline $\begin{array}{l}\text { Hradiste pod } \\
\text { Vratnom / Hradist }\end{array}$ & 48.626 & 17.487 & - & $\geq \mathrm{VII}$ & „Der Schwefelgehalt der Quelle stieg an." & $\begin{array}{l}\text { "The sulfur content of the spring } \\
\text { increased." }\end{array}$ \\
\hline Bukovec / Bukóc & 48.700 & 17.496 & - & VIII-IX & $\begin{array}{l}\text { "In vielen Brunnen versiegte das } \\
\text { Wasser." }\end{array}$ & "Many wells fell dry." \\
\hline
\end{tabular}

Tab. 1: Contemporary descriptions of environmental effects of the 1906 Dobrá Voda / Jókeö earthquake and its strongest aftershock from Réthly (1907). Location names are given in Slovak and Hungarian language. Forel-Mercalli intensity taken from Réthly (1907). See text and Table 2 for explanation and discussion of assigned ESI 2007 intensities. 
$16^{\circ} \mathrm{E}$

$18^{\circ} \mathrm{E}$

$19^{\circ} \mathrm{E}$
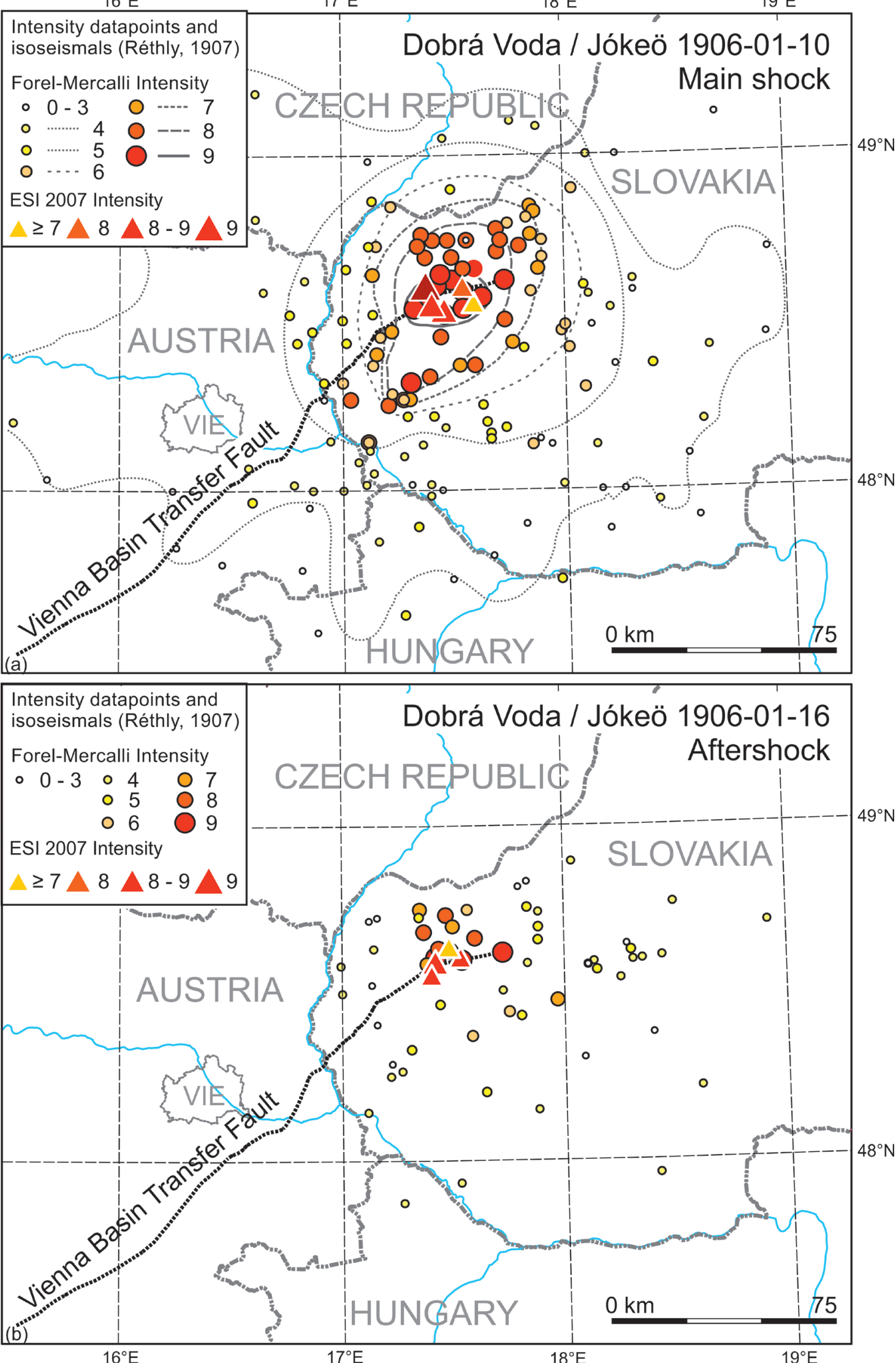

Fig. 2: Map of intensity data points for the 10.01.1906 Dobrá Voda mainshock (a) and the 16.01.1906 aftershock (b). Intensity values related to the 12part Forel-Mercalli scale (Cancani, 1904, taken from Réthly, 1907) and to the ESI scale (Michetti et al., 2007). Original isoseismic contour lines from Réthly (1907) are included as thin black lines for reference. The felt area for the mainshock in panel (a) is almost $30.000 \mathrm{~km}^{2}$. International borders are shown as dashed grey lines. 


\begin{tabular}{|c|c|c|c|c|c|}
\hline IESI & Description & Hydrological anomalies & Ground cracks & Slope movement & $\begin{array}{l}\text { Area } \\
\left(\mathbf{k m}^{2}\right)\end{array}$ \\
\hline VII & Damaging & $\begin{array}{l}\text { Significant temporary variations of the } \\
\text { water level in wells and/or of the flow-rate } \\
\text { of springs are locally recorded. Seldom, } \\
\text { small springs may temporarily run dry or } \\
\text { appear. Weak variations of chemical-physical } \\
\text { properties of water and turbidity in lakes, } \\
\text { springs and wells are locally observed. }\end{array}$ & $\begin{array}{l}\text { Fractures up to } 5-10 \mathrm{~cm} \text { wide and } \\
\text { up to hundred metres long are } \\
\text { observed, commonly in loose } \\
\text { alluvial deposits and/or saturated } \\
\text { soils; rarely, in dry sand, sand-clay, } \\
\text { and clay soil fractures are also } \\
\text { seen, up to } 1 \mathrm{~cm} \text { wide. }\end{array}$ & $\begin{array}{l}\text { Scattered landslides occur } \\
\text { in prone areas, where } \\
\text { equilibrium is unstable (steep } \\
\text { slopes of loose / saturated } \\
\text { soils)... }\end{array}$ & 10 \\
\hline VIII & $\begin{array}{l}\text { Heavily } \\
\text { damaging }\end{array}$ & $\begin{array}{l}\text { Springs may change, generally temporarily, } \\
\text { their flow-rate and/or elevation of outcrop. } \\
\text { Some small springs may even run dry. } \\
\text { Variations in water level are observed in } \\
\text { wells. Weak variations of chemical-physical } \\
\text { properties of water, most commonly } \\
\text { temperature, may be observed... Water } \\
\text { turbidity may appear... Gas emissions, } \\
\text { often sulphureous, are locally observed. }\end{array}$ & $\begin{array}{l}\text { Fractures up to } 50 \mathrm{~cm} \text { wide and } \\
\text { up to hundreds metres long, } \\
\text { are commonly observed in loose } \\
\text { alluvial deposits and/or saturated } \\
\text { soils; in rare cases fractures up } \\
\text { to } 1 \mathrm{~cm} \text { can be observed in } \\
\text { competent dry rocks. Decimetric } \\
\text { cracks arecommon in paved } \\
\text { (asphalt or stone) roads, as well as } \\
\text { small pressure undulations. }\end{array}$ & $\begin{array}{l}\text { Small to moderate }\left(10^{3} \text { - }\right. \\
\left.10^{5} \mathrm{~m}^{3}\right) \text { landslides are } \\
\text { widespread in prone areas; } \\
\text { rarely they can occur also } \\
\text { on gentle slopes; where } \\
\text { equilibrium is unstable } \\
\text { (steep slopes of loose / } \\
\text { saturated soils; rock falls on } \\
\text { steep gorges, coastal cliffs) } \\
\text { their size is sometimes large } \\
\left(10^{5}-10^{6} \mathrm{~m}^{3}\right) \text {. }\end{array}$ & 100 \\
\hline IX & Destructive & $\begin{array}{l}\text { Springs can change, generally temporarily, } \\
\text { their flow-rate and/or location to a } \\
\text { considerable extent. Some modest springs } \\
\text { may even run dry. Temporary variations } \\
\text { of water level are commonly observed } \\
\text { in wells. Variations of chemical-physical } \\
\text { properties of water, most commonly } \\
\text { temperature, are observed... Water turbidity } \\
\text { is common ... Gas emissions, often } \\
\text { sulphureous, are observed... }\end{array}$ & $\begin{array}{l}\text { Fractures up to } 100 \mathrm{~cm} \text { wide and } \\
\text { up to hundreds metres long } \\
\text { are commonly observed in loose } \\
\text { alluvial deposits and/or saturated } \\
\text { soils; in competent rocks they } \\
\text { can reach up to } 10 \mathrm{~cm} \text {. Significant } \\
\text { cracks are common in paved } \\
\text { (asphalt or stone) roads, as well as } \\
\text { small pressure undulations. }\end{array}$ & $\begin{array}{l}\text { Landsliding is widespread in } \\
\text { prone areas, also on gentle } \\
\text { slopes; where equilibrium } \\
\text { is unstable (steep slopes of } \\
\text { loose / saturated soils; rock } \\
\text { falls on steep gorges, coastal } \\
\text { cliffs) their size is frequently } \\
\text { large }\left(10^{5} \mathrm{~m}^{3}\right) \text {, sometimes } \\
\text { very large }\left(106 \mathrm{~m}^{3}\right) \text {. }\end{array}$ & 1,000 \\
\hline $\mathrm{x}$ & $\begin{array}{l}\text { Very } \\
\text { destructive }\end{array}$ & $\begin{array}{l}\text { Many springs significantly change their } \\
\text { flow-rate and/or elevation of outcrop. } \\
\text { Some springs may run temporarily or even } \\
\text { permanently dry. Temporary variations of } \\
\text { water level are commonly observed in wells. } \\
\text { Even strong variations of chemical-physical } \\
\text { properties of water, most commonly } \\
\text { temperature, are observed... Often water } \\
\text { becomes very muddy... Gas emissions, } \\
\text { often sulphureous, are observed. }\end{array}$ & $\begin{array}{l}\text { Open ground cracks up to } \\
\text { more than } 1 \text { m wide and up } \\
\text { to hundred metres long are } \\
\text { frequent, mainly in loose alluvial } \\
\text { deposits and/or saturated soils; } \\
\text { in competent rocks opening } \\
\text { reaches several decimeters. } \\
\text { Wide cracks develop in paved } \\
\text { (asphalt or stone) roads, as well as } \\
\text { pressure undulations. }\end{array}$ & $\begin{array}{l}\text { Large landslides and } \\
\text { rock-falls }\left(>10^{5}-10^{6} \mathrm{~m}^{3}\right) \\
\text { are frequent, practically } \\
\text { regardless of equilibrium } \\
\text { state of slopes, causing } \\
\text { temporary or permanent } \\
\text { barrier lakes. }\end{array}$ & 5,000 \\
\hline
\end{tabular}

Tab. 2: Shortened version of the definitions of the intensity classes VII to X according to the ESI 2007. The full text of the intensity definitions provided by Michetti et al. (2007) was used for the assessment of the effects of the 1906 Dobrá Voda earthquake.

between $|E S| \geq V \mid I$ and $I X$. The intensity is in agreement with the minimum area of about $80 \mathrm{~km}^{2}$ spanned by the locations mentioned by Réthly (1907), supporting IESI-2007=VIII for the aftershock. In total, the reported intensity data points of the mainshock indicate ESI intensities between VIII and X in the epicentral area of the mainshock. However, the absence of descriptions of surface faulting and the absence of descriptions of ground cracks other than those related to landsliding points to a maximum intensity of the 1906 Dobrá Voda of less than $|E S|=X$. At the ESI intensity of $X$, primary effects of surface faulting should be "leading", and up to more than $1 \mathrm{~m}$ wide and up to hundred meters long cracks should be frequent (Michetti, 2007). We therefore assess the ESI intensity of the mainshock as $|E S|=\mid X$.

As seen in Tab. 1 and Fig. 2a, the ESI 2007 intensity estimations for the mainshock on 10.01.1906 are comparable to the results of macroseismic intensity assessment by Réthly (1907), but slightly higher than the assessments of Imax by Grünthal et al. (2009) and ACORN (2004), which denote intensity VIII-IX for the event. Among the four ESI 2007 intensity datapoints available for the aftershock on 16.01.1906, the one from Jablonica ("Well water of the entire surroundings was turbid") indicates the highest intensity leading to assign IESI-2007=IX (Tab. 1, Fig. 2). Descriptions from two locations are indicative for IESI-2007=VIII-IX, one for IESI-2007 $\geq$ VII. The area of about $80 \mathrm{~km}^{2}$ from which hydrological effects were reported is indicative for IESI-2007=VII-VIII (Tab. 2). We conclude that $\mathrm{I}_{0}=\mathrm{VIII}$ is more appropriately describes the maximum intensity of the event than $\mathrm{I}_{0}=\mathrm{VII}-\mathrm{VIII}$ as listed in ACORN (2004) and Grünthal et al. (2009).

\subsection{Earthquake occurrence near the 1906 Dobrá Voda mainshock}

The most common and practical way of automatic aftershock detection is the use of temporal and spatial windows with the window length and size scaled according to the magnitude of the mainshock (Gardner and Knopoff, 1974). As the proposed spatial window size (about 50 
$\mathrm{km}$ for $5.5<M<6.0)$ seems too large for the investigated event, we calculated the rupture length for an earthquake with $M=5.7$ using the following equation (Wells and Coppersmith, 1994):

$$
\text { Log }(\text { Radial distance in } \mathrm{m})=(\mathrm{M}-4.32) / 1.54
$$

As the aftershocks tend to occur on the ruptured fault plane, the rupture length can be used to constrain the maximum epicentral distance of aftershocks from the mainshock. The regression by Wells \& Coppersmith (1994) would suggest a radius of about $10 \mathrm{~km}$ around the epicenter as a spatial window for aftershock of the $M s=5.7$ earthquake (Tab. 3). To account for the inaccuracies of macroseismic hypocenter locations resulting from the distance between the different settlements for which intensity data points are available, we extended the region under consideration to a radius of $13 \mathrm{~km}$.

For a further assessment and to account for possibly even larger uncertainties of epicentre locations of historical events, we compared the seismicity distribution for a larger region with twice the radius of the previous spatial window $(26 \mathrm{~km})$. This extension approximates the hypocentre uncertainty for pre-instrumental earthquakes during the 20th century (Gangl and Decker, 2011). Fig. 3 shows the seismic activity around the mainshock (red star) from the ACORN catalogue (2004). Seismicity is shown by for a radial distance of $13 \mathrm{~km}$ (green circles) and $26 \mathrm{~km}$ (blue circles) from the epicenter of the mainshock. Most earthquakes are located within $5-10 \mathrm{~km}$ of the mainshock (Fig. 4), justifying the definition of aftershocks within the $13 \mathrm{~km}$ radius of epicentral distance.

The temporal distribution of earthquakes prior and after the 10.01.1906 mainshock shows an interesting pattern (Fig. 5). Prior to the 20th century, several earthquakes with magnitudes larger than 4.0 were recorded in the study area, fitting well to the considered completeness magnitude of 4.0 for the ACORN catalogue (Nasir et al., 2013). However, no major earthquake has been recorded in the vicinity of the mainshock. Earthquakes with magnitudes of approximately $M=2.7$ (corresponding to $I_{0}=I V$ )

\begin{tabular}{|c|c|c|}
\hline Magnitude & $\mathrm{L}(\mathrm{km})$ & $\mathrm{T}$ (days) \\
\hline 4.5 & 10 & 83 \\
\hline 5.0 & 10 & 155 \\
\hline 5.5 & 10 & 290 \\
\hline 6.0 & 13 & 510 \\
\hline 6.5 & 26 & 790 \\
\hline 7.0 & 54 & 915 \\
\hline
\end{tabular}

Tab. 3: Values from the window algorithm for automatic detection of fore- and aftershocks based on temporal $(T=$ days after the mainshock (Knopoff and Gardner, 1969) and spatial windows ( $\mathrm{L}=$ radial distance from epicenter in $\mathrm{km}$ ). Spatial windows follow the equation Log (Radial distance in $\mathrm{km})=(\mathrm{M}-4.32) / 1.54$ (Wells and Coppersmith, 1994). The lower limit for the spatial window is set to $10 \mathrm{~km}$ due to high uncertainties associated with macroseismically determined epicentres of historical earthquakes. For explanation for the usage of the Wells and Coppersmith (1994) relation see text. are reported consistently since 1850 . As expected, the mainshock caused the onset of elevated earthquake activity in its vicinity, and the seismicity shifts to its close surrounding, with the strongest $(M=5)$ event occurring on 05.03 .1930 . In contrast, seismicity in the wider $26 \mathrm{~km}$ area almost stops completely for the next 70 years after the mainshock (Fig. 6). Normally, earthquakes are considered as aftershocks as long as the seismic activity level is above the background seismicity defined as the activity level prior to the mainshock. Applying this rule to the earthquake distribution shown in Fig. 5, earthquakes with magnitudes larger than 4.0 seem to decrease to background level between the 1930s and 1950s.

In comparison, earthquakes of magnitudes between 2.5 and 4.0 were recorded only sparsely before the mainshock but are abundant in the 20th century. It is interesting to note that almost all of them occur close to the mainshock within $13 \mathrm{~km}$ of epicentral distance. So, compared to the pre-mainshock seismic activity level within the $13 \mathrm{~km}$ radius, the moderate seismic activity in this area was elevated until about 2000 AD. Using the outer area of $13-26 \mathrm{~km}$ distance to the mainshock as reference level for background seismicity, the seismic activity ceases to background level at around 1980 AD. Unfortunately, data gaps due the war times of WWI and WWII (1914-18 and 1939-1945) and the following decades of recovery coincide with the analyzed period. The activity rates before and after the record gaps show regular exponential patterns of decaying seismicity.

The standard length of the time window where earthquakes are considered as aftershocks according to Gardner and Knopoff (1974) would be about 380 days for the 10.01.1906 and 155 days for the 05.03.1930 $(M=5)$ Dobrá Voda earthquakes. The time windows interpolated from the values given in Table 3 are shown in Fig. 6 as gray vertical bars. This indicates that the time window from this method seems too short to include all potential aftershocks of the 1906 earthquake. In contrast, today's apparently still elevated seismicity and the overall gradual reduction of the seismicity level following the earthquake until today closely resembles a long-lasting aftershock succession as proposed for slow intra-plate faults by Stein and Liu (2009).

\section{Discussion}

In general, the major criteria for determining aftershock duration is the change in seismicity rates from decaying aftershocks to background seismicity, which can be directly measured for short aftershock durations. However, identifying this transition becomes difficult and even impossible as the aftershock duration approaches or exceeds the length of earthquake records (Stein and Liu, 2009). In case of the Dobrá Voda earthquake, determining the pre-event background seismicity poses another challenge, as earthquake recording changes at the same time from macroseismic to instrumentally supported observations. In the following, we discuss therefore the completeness of the pre-1906 earthquake records and 


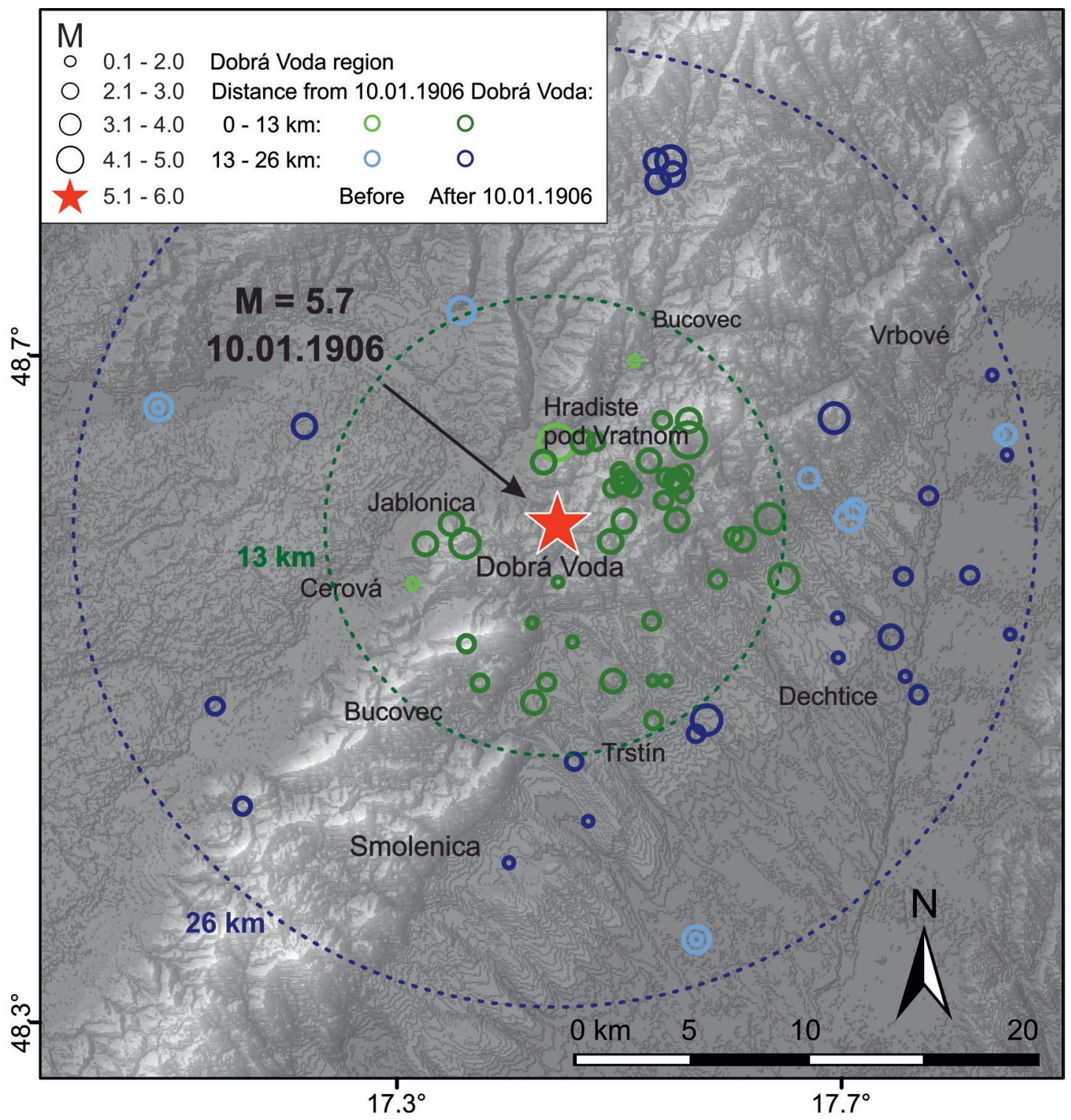

Fig. 3: Seismicity in the vicinity of the 1906 Dobrá Voda earthquake (M/I0=5.7/VIII-IX). Blue and green circles indicate earthquakes within a 0-13 km and 13-26 km distance from the mainshock. Light colors denote earthquakes before the mainshock, darker colors earthquakes after the mainshock. Data are listed in Tab. 4

the resulting background seismicity, and then compare it to the earthquake distribution after 1906.

Fig. 5 shows that several earthquakes with $M=4-5$ occurred within a distance of 13-26 km from the epicenter of the 1906 Dobrá Voda mainshock between about 1500 and 1900. However, no aftershocks of these earthquakes have been recorded, most probably due to the general lack of detailed descriptions for these historical events. The observation threshold of $\mathrm{M} \approx 4.0$ for the time before 1815 is clearly seen, with a recurrence interval of about 100 years for earthquakes larger than $\mathrm{M}=4.0$. In contrast, the main Dobrá Voda earthquake was followed by several strong earthquakes on 16.01.1906 ( $M=5.1), 18.04 .1914(M=5.1), 05.03 .1930(M=5.0)$ and 06.03.1930 $(M=4.6)$ in much shorter intervals.

The next strong earthquake after the apparent lack of data due to World War II (Figs. 5 and 6) occurred on 03.12.1967 ( $M=4.3)$ close to Dobrá Voda. As the 1967 earthquake occurred approximately 100 years after the
$1852(M=4.3)$ Pernek earthquake, its occurrence fits well to the level of seismicity observed before the 1906 earthquake. Considering this as background seismicity, the elevated seismicity caused by the 1906 mainshock would have lasted at least until 1930. On the other hand, considering that this earthquake occurred to close to the epicenter of the 1906 mainshock, it would be also reasonable to include it into a long-lasting aftershock sequence.

The systematic recording of smaller earthquakes with magnitudes down to $M \approx 2.6$ (IO $\approx \mathrm{IV})$ in the former Austrian empire started around 1895 (Nasir et al., 2013). However, the period between 1800 and 1900, and especially since 1850, may be regarded as complete enough to define the "background seismicity" before the 1906 mainshock (Fig. 5). The observational threshold for this period is $M \approx 2.6$ except for the periods of non-recording around WWI and WWII. In spite of the low record threshold, almost no earthquake larger than $M=3.0$ was recorded at 


\begin{tabular}{|c|c|c|c|c|c|}
\hline Date & Lat & Long & M & $I_{0}$ & Epicentre \\
\hline 26.02 .1515 & 48,37 & 17,56 & 5 & 7 & Trnava \\
\hline 1586 & 48,37 & 17,56 & 4,6 & 7 & Trnava \\
\hline 30.11 .1660 & 48,37 & 17,56 & 4,4 & 6 & Trnava \\
\hline 1805 & 48,58 & 17,68 & 4,3 & 6 & Dobrá Voda \\
\hline 1815 & 48,6 & 17,65 & 3,2 & 4 & Lancar \\
\hline 15.06 .1815 & 48,58 & 17,68 & 3,2 & 4 & Dobrá Voda \\
\hline 15.11 .1852 & 48,64 & 17,16 & 4,3 & 6 & Pernek - \\
\hline 13.04 .1860 & 48,37 & 17,56 & 2,6 & 3 & Trnava \\
\hline 13.04 .1860 & 48,37 & 17,56 & 2,6 & 3 & Trnava \\
\hline 15.11 .1865 & 48,64 & 17,16 & 2,6 & 3 & Sastin \\
\hline 15.11 .1865 & 48,64 & 17,16 & 2,6 & 3 & Sastin \\
\hline 01.02 .1873 & 48,37 & 17,56 & 2,6 & 3 & Trnava \\
\hline 02.12 .1874 & 48,66 & 17,52 & 2,6 & 3 & Pernek-Modra \\
\hline 24.03.1893 & 48,62 & 17,8 & 3,8 & 6 & Dobrá Voda \\
\hline $28.03 .1893^{*}$ & 48,62 & 17,8 & 2,6 & 6 & Dobrá Voda \\
\hline 04.03 .1894 & 48,6 & 17,51 & 2,6 & 3 & Dobrá Voda \\
\hline 19.04.1904 & 48,6 & 17,51 & 2,6 & 3 & Dobrá Voda \\
\hline 20.04.1904 & 48,62 & 17,46 & 4,5 & 7 & Dobrá Voda \\
\hline 12.10 .1904 & 48,68 & 17,39 & 4,3 & 6 & Dobrá Voda \\
\hline 10.04.1905 & 48,55 & 17,35 & 2,6 & 3 & Sandorfal \\
\hline 09.01.1906 & 48,58 & 17,46 & 5,7 & 9 & Dobrá Voda \\
\hline 10.01 .1906 & 48,63 & 17,27 & 2,6 & 3 & Dobrá Voda \\
\hline 10.01.1906 & 48,75 & 17,54 & 2,6 & 3 & Dobrá Voda \\
\hline 10.01.1906 & 48,63 & 17,56 & 3,7 & 5 & Dobrá Voda \\
\hline 10.01 .1906 & 48,57 & 17,6 & 2,6 & 3 & Dobrá Voda \\
\hline 15.01.1906 & 48,6 & 17,55 & 3,2 & 4 & Dobrá Voda \\
\hline 16.01.1906 & 48,6 & 17,51 & 2,6 & 3 & Dobrá Voda \\
\hline 16.01 .1906 & 48,6 & 17,51 & 2,6 & 3 & Dobrá Voda \\
\hline 16.01.1906 & 48,6 & 17,51 & 2,6 & 3 & Dobrá Voda \\
\hline 16.01.1906 & 48,6 & 17,51 & 2,6 & 3 & Dobrá Voda \\
\hline 16.01.1906 & 48,6 & 17,51 & 2,6 & 3 & Dobrá Voda \\
\hline 16.01 .1906 & 48,62 & 17,56 & 5,1 & 8 & Dobrá Voda \\
\hline 17.01 .1906 & 48,6 & 17,51 & 2,6 & 3 & Dobrá Voda \\
\hline 17.01 .1906 & 48,6 & 17,51 & 2,6 & 3 & Dobrá Voda \\
\hline 17.01 .1906 & 48,6 & 17,55 & 2,6 & 3 & Dobrá Voda \\
\hline 19.01 .1906 & 48,6 & 17,51 & 2,6 & 3 & Dobrá Voda \\
\hline 19.01.1906 & 48,6 & 17,51 & 2,6 & 3 & Dobrá Voda \\
\hline 20.01.1906 & 48,6 & 17,51 & 2,6 & 3 & Dobrá Voda \\
\hline 04.02 .1906 & 48,6 & 17,51 & 2,6 & 3 & Dobrá Voda \\
\hline 04.02 .1906 & 48,6 & 17,51 & 2,9 & 4 & Dobrá Voda \\
\hline 08.02 .1906 & 48,6 & 17,51 & 2,6 & 3 & Dobrá Voda \\
\hline 10.02.1906 & 48,6 & 17,51 & 2,6 & 3 & Dobrá Voda \\
\hline 12.02 .1906 & 48,6 & 17,55 & 3,2 & 4 & Dobrá Voda \\
\hline 14.02 .1906 & 48,6 & 17,55 & 2,6 & 3 & Dobrá Voda \\
\hline 15.02.1906 & 48,6 & 17,55 & 2,6 & 3 & Dobrá Voda \\
\hline 15.02 .1906 & 48,6 & 17,55 & 2,6 & 3 & Dobrá Voda \\
\hline 20.02 .1906 & 48,6 & 17,55 & 2,6 & 3 & Dobrá Voda \\
\hline 21.02 .1906 & 48,6 & 17,55 & 2,6 & 3 & Dobrá Voda \\
\hline 21.02.1906 & 48,6 & 17,55 & 3,7 & 5 & Dobrá Voda \\
\hline 22.02.1906 & 48,6 & 17,51 & 2,6 & 3 & Dobrá Voda \\
\hline 22.02.1906 & 48,6 & 17,51 & 2,9 & 4 & Dobrá Voda \\
\hline 24.04 .1906 & 48,6 & 17,51 & 2,6 & 3 & Dobrá Voda \\
\hline
\end{tabular}

\begin{tabular}{|c|c|c|c|c|c|}
\hline Date & Lat & Long & $M$ & $I_{0}$ & Epicentre \\
\hline 22.02.1906 & 48,6 & 17,51 & 3,2 & 4 & Dobrá Voda \\
\hline 22.02 .1906 & 48,6 & 17,51 & 3,4 & 5 & Dobrá Voda \\
\hline 25.02 .1906 & 48,6 & 17,51 & 2,6 & 3 & Dobrá Voda \\
\hline 25.02 .1906 & 48,6 & 17,51 & 2,6 & 3 & Dobrá Voda \\
\hline 25.02.1906 & 48,6 & 17,51 & 2,9 & 4 & Dobrá Voda \\
\hline 25.02.1906 & 48,6 & 17,51 & 3,2 & 4 & Dobrá Voda \\
\hline 26.02 .1906 & 48,6 & 17,51 & 2,9 & 4 & Dobrá Voda \\
\hline 28.02.1906 & 48,6 & 17,51 & 2,9 & 4 & Dobrá Voda \\
\hline 28.02.1906 & 48,6 & 17,51 & 2,9 & 4 & Dobrá Voda \\
\hline 01.03.1906 & 48,6 & 17,51 & 3,2 & 4 & Dobrá Voda \\
\hline 02.03.1906 & 48,58 & 17,51 & 3,4 & 5 & Dobrá Voda \\
\hline 02.03 .1906 & 48,6 & 17,51 & 3,2 & 4 & Dobrá Voda \\
\hline 02.03.1906 & 48,6 & 17,55 & 3,7 & 5 & Dobrá Voda \\
\hline 03.03.1906 & 48,6 & 17,51 & 3,2 & 4 & Dobrá Voda \\
\hline 03.03.1906 & 48,6 & 17,51 & 3,2 & 4 & Dobrá Voda \\
\hline 08.03.1906 & 48,6 & 17,51 & 3,2 & 4 & Dobrá Voda \\
\hline 09.03.1906 & 48,6 & 17,51 & 3,7 & 5 & Dobrá Voda \\
\hline 13.03.1906 & 48,6 & 17,51 & 2,9 & 4 & Dobrá Voda \\
\hline $16.03 .1906^{*}$ & 48,62 & 17,48 & 3,2 & 5 & Jablonica \\
\hline 23.03.1906 & 48,6 & 17,51 & 2,6 & 3 & Dobrá Voda \\
\hline 24.03.1906 & 48,63 & 17,54 & 2,9 & 4 & Dobrá Voda \\
\hline 25.03 .1906 & 48,6 & 17,55 & 3,8 & 5 & Dobrá Voda \\
\hline 31.03 .1906 & 48,6 & 17,51 & 2,8 & 4 & Dobrá Voda \\
\hline 31.03 .1906 & 48,6 & 17,51 & 2,9 & 4 & Dobrá Voda \\
\hline 01.04 .1906 & 48,6 & 17,51 & 3,2 & 4 & Dobrá Voda \\
\hline 02.04 .1906 & 48,6 & 17,51 & 2,6 & 3 & Dobrá Voda \\
\hline 02.04 .1906 & 48,6 & 17,51 & 2,6 & 3 & Dobrá Voda \\
\hline 02.04 .1906 & 48,6 & 17,55 & 2,6 & 3 & Dobrá Voda \\
\hline 06.04.1906 & 48,6 & 17,51 & 2,9 & 4 & Dobrá Voda \\
\hline 07.04.1906 & 48,6 & 17,51 & 2,6 & 3 & Dobrá Voda \\
\hline 07.04.1906 & 48,6 & 17,51 & 2,6 & 3 & Dobrá Voda \\
\hline 07.04.1906 & 48,6 & 17,51 & 3,2 & 4 & Dobrá Voda \\
\hline 07.04.1906 & 48,6 & 17,51 & 3,7 & 5 & Dobrá Voda \\
\hline 07.04 .1906 & 48,6 & 17,55 & 2,6 & 3 & Dobrá Voda \\
\hline 08.04 .1906 & 48,6 & 17,51 & 2,6 & 3 & Dobrá Voda \\
\hline 08.04 .1906 & 48,6 & 17,51 & 2,9 & 4 & Dobrá Voda \\
\hline 08.04.1906 & 48,6 & 17,51 & 2,9 & 4 & Dobrá Voda \\
\hline 09.04 .1906 & 48,62 & 17,49 & 2,9 & 4 & Dobrá Voda \\
\hline 09.04.1906 & 48,6 & 17,51 & 2,6 & 3 & Dobrá Voda \\
\hline 09.04 .1906 & 48,53 & 17,53 & 2,6 & 3 & Nahac \\
\hline 09.04 .1906 & 48,61 & 17,53 & 3,7 & 5 & Dobrá Voda \\
\hline 12.04.1906 & 48,6 & 17,51 & 2,6 & 3 & Dobrá Voda \\
\hline 12.04 .1906 & 48,6 & 17,51 & 2,9 & 4 & Dobrá Voda \\
\hline 12.04 .1906 & 48,6 & 17,51 & 3,2 & 4 & Dobrá Voda \\
\hline 13.04.1906 & 48,6 & 17,51 & 2,6 & 3 & Dobrá Voda \\
\hline 15.04.1906 & 48,61 & 17,45 & 3,4 & 5 & Dobrá Voda \\
\hline 15.04 .1906 & 48,6 & 17,51 & 2,6 & 3 & Dobrá Voda \\
\hline 19.04.1906 & 48,61 & 17,45 & 3,3 & 5 & Dobrá Voda \\
\hline 22.04.1906 & 48,6 & 17,51 & 2,6 & 3 & Dobrá Voda \\
\hline 23.04.1906 & 48,6 & 17,51 & 3,2 & 4 & Dobrá Voda \\
\hline 23.04 .1906 & 48,6 & 17,51 & 3,2 & 4 & Dobrá Voda \\
\hline 07.03.1930 & 48,6 & 17,51 & 2,6 & 3 & Dobrá Voda \\
\hline
\end{tabular}




\begin{tabular}{|c|c|c|c|c|c|}
\hline Date & Lat & Long & $\mathbf{M}$ & $I_{0}$ & Epicentre \\
\hline 25.04 .1906 & 48,6 & 17,51 & 2,6 & 3 & Dobrá Voda \\
\hline 10.05 .1906 & 48,6 & 17,51 & 2,6 & 3 & Dobrá Voda \\
\hline 12.05 .1906 & 48,6 & 17,51 & 2,6 & 3 & Dobrá Voda \\
\hline 15.05.1906 & 48,6 & 17,51 & 3,4 & 5 & Dobrá Voda \\
\hline 31.05 .1906 & 48,6 & 17,51 & 2,6 & 3 & Dobrá Voda \\
\hline 31.05 .1906 & 48,6 & 17,51 & 3,2 & 4 & Dobrá Voda \\
\hline 01.06 .1906 & 48,63 & 17,67 & 3,4 & 5 & Dobrá Voda \\
\hline 02.06 .1906 & 48,6 & 17,51 & 2,9 & 4 & Dobrá Voda \\
\hline 07.06.1906 & 48,57 & 17,6 & 3,2 & 4 & Dobrá Voda \\
\hline 20.06.1906 & 48,6 & 17,51 & 2,9 & 4 & Dobrá Voda \\
\hline 04.07.1906 & 48,6 & 17,51 & 2,8 & 4 & Dobrá Voda \\
\hline 08.08.1906 & 48,6 & 17,51 & 2,6 & 3 & Dobrá Voda \\
\hline 09.08 .1906 & 48,6 & 17,55 & 2,6 & 3 & Dobrá Voda \\
\hline 10.08.1906 & 48,6 & 17,55 & 2,6 & 3 & Dobrá Voda \\
\hline 13.08.1906 & 48,6 & 17,51 & 2,6 & 3 & Dobrá Voda \\
\hline 14.08 .1906 & 48,6 & 17,51 & 2,6 & 3 & Dobrá Voda \\
\hline 15.08.1906 & 48,6 & 17,51 & 2,6 & 3 & Dobrá Voda \\
\hline 16.08 .1906 & 48,6 & 17,51 & 2,6 & 3 & Dobrá Voda \\
\hline 16.08.1906 & 48,6 & 17,55 & 2,6 & 3 & Dobrá Voda \\
\hline 17.08.1906 & 48,55 & 17,58 & 2,6 & 3 & Dobrá Voda \\
\hline 25.08 .1906 & 48,6 & 17,51 & 3,2 & 4 & Dobrá Voda \\
\hline 06.09.1906 & 48,6 & 17,51 & 3,2 & 4 & Dobrá Voda \\
\hline 11.09 .1906 & 48,6 & 17,51 & 3,2 & 4 & Dobrá Voda \\
\hline 16.03.1908 & 48,6 & 17,51 & 2,9 & 4 & Dobrá Voda \\
\hline 25.05.1908 & 48,6 & 17,55 & 2,6 & 3 & Dobrá Voda \\
\hline 26.05 .1908 & 48,6 & 17,55 & 2,6 & 3 & Dobrá Voda \\
\hline 18.12 .1908 & 48,6 & 17,51 & 3,2 & 4 & Dobrá Voda \\
\hline 04.01 .1909 & 48,6 & 17,51 & 2,6 & 3 & Dobrá Voda \\
\hline 08.01 .1909 & 48,6 & 17,51 & 2,6 & 3 & Dobrá Voda \\
\hline 09.01 .1909 & 48,6 & 17,51 & 2,6 & 3 & Dobrá Voda \\
\hline 14.03.1909 & 48,6 & 17,51 & 3,7 & 5 & Dobrá Voda \\
\hline 16.01.1910 & 48,6 & 17,51 & 2,6 & 3 & Dobrá Voda \\
\hline 06.09.1929 & 48,58 & 17,55 & 3,4 & 5 & Dobrá Voda \\
\hline 04.03 .1930 & 48,46 & 17,47 & 2,3 & 3 & Dobrá Voda \\
\hline 04.03 .1930 & 48,6 & 17,51 & 3,7 & 5 & Dobrá Voda \\
\hline 05.03 .1930 & 48,6 & 17,51 & 2,2 & 3 & Dobrá Voda \\
\hline 05.03.1930 & 48,6 & 17,51 & 2,6 & 3 & Dobrá Voda \\
\hline 05.03 .1930 & 48,58 & 17,62 & 5 & 8 & Dobrá Voda \\
\hline 06.03 .1930 & 48,5 & 17,45 & 2,6 & 3 & Dobrá Voda \\
\hline 06.03 .1930 & 48,6 & 17,51 & 2,6 & 3 & Dobrá Voda \\
\hline 06.03 .1930 & 48,6 & 17,51 & 2,6 & 3 & Dobrá Voda \\
\hline 06.03.1930 & 48,6 & 17,51 & 2,6 & 3 & Dobrá Voda \\
\hline 06.03 .1930 & 48,6 & 17,51 & 2,6 & 3 & Dobrá Voda \\
\hline 06.03 .1930 & 48,6 & 17,51 & 2,6 & 3 & Dobrá Voda \\
\hline 06.03 .1930 & 48,6 & 17,51 & 3 & 4 & Dobrá Voda \\
\hline 06.03 .1930 & 48,6 & 17,51 & 3,2 & 4 & Dobrá Voda \\
\hline 06.03 .1930 & 48,48 & 17,53 & 2,6 & 3 & Dobrá Voda \\
\hline 06.03.1930 & 48,55 & 17,63 & 4,6 & 7 & Dobrá Voda \\
\hline 07.03.1930 & 48,6 & 17,51 & 2,6 & 3 & Dobrá Voda \\
\hline 07.03.1930 & 48,6 & 17,51 & 2,6 & 3 & Dobrá Voda \\
\hline
\end{tabular}

\begin{tabular}{|c|c|c|c|c|c|}
\hline Date & Lat & Long & M & $I_{0}$ & Epicentre \\
\hline 07.03.1930 & 48,6 & 17,51 & 2,6 & 3 & Dobrá Voda \\
\hline 07.03.1930 & 48,6 & 17,51 & 3,2 & 4 & Dobrá Voda \\
\hline 08.03.1930 & 48,6 & 17,51 & 2,6 & 3 & Dobrá Voda \\
\hline 09.03 .1930 & 48,6 & 17,51 & 2,6 & 3 & Dobrá Voda \\
\hline 09.03.1930 & 48,6 & 17,51 & 2,6 & 3 & Dobrá Voda \\
\hline 15.03.1930 & 48,6 & 17,51 & 2,6 & 3 & Dobrá Voda \\
\hline 17.03.1930 & 48,6 & 17,51 & 2,6 & 3 & Dobrá Voda \\
\hline 17.03.1930 & 48,6 & 17,51 & 3,4 & 5 & Dobrá Voda \\
\hline 18.03.1930 & 48,6 & 17,51 & 2,6 & 3 & Dobrá Voda \\
\hline 18.03.1930 & 48,6 & 17,51 & 2,6 & 3 & Dobrá Voda \\
\hline 13.12.1955 & 48,49 & 17,44 & 3,2 & 4 & Pernek-Modra \\
\hline 22.06 .1957 & 48,5 & 17,4 & 2,6 & 3 & Smolenice \\
\hline 01.07.1957 & 48,5 & 17,4 & 2,9 & 4 & Smolenice \\
\hline 03.07.1957 & 48,5 & 17,4 & 2,6 & 3 & Smolenice \\
\hline 04.07.1957 & 48,5 & 17,4 & 2,3 & 3 & Smolenice \\
\hline 17.06.1967 & 48,58 & 17,38 & 3,7 & 5 & Dobrá Voda \\
\hline 03.12 .1967 & 48,57 & 17,39 & 4,3 & 7 & Dobrá Voda \\
\hline 26.07.1976 & 48,76 & 17,55 & 3,2 & 4 & Pernek-Modra \\
\hline 28.07.1976 & 48,76 & 17,55 & 3,2 & 4 & Pernek-Modra \\
\hline 05.08 .1976 & 48,76 & 17,55 & 2,9 & 4 & Pernek-Modra \\
\hline 19.08.1976 & 48,76 & 17,55 & 2,9 & 4 & Pernek-Modra \\
\hline 24.08.1976 & 48,57 & 17,36 & 4 & 6 & Pernek-Modra \\
\hline 11.04.1977 & 48,5 & 17,5 & 3,4 & 5 & Dobrá Voda \\
\hline 21.03.1980 & 48,5 & 17,4 & 2,9 & 4 & Pernek - \\
\hline 13.03.1987 & 48,59 & 17,74 & 2,4 & & Dobrá Voda \\
\hline 22.03.1987 & 48,47 & 17,56 & 2,3 & & Dobrá Voda \\
\hline 30.05 .1987 & 48,52 & 17,71 & 2,8 & & Dobrá Voda \\
\hline 01.07.1987 & 48,52 & 17,39 & 2,3 & & Dobrá Voda \\
\hline 12.03 .1989 & 48,49 & 17,2 & 2,3 & & Plavecke \\
\hline 21.10.1991 & 48,57 & 17,5 & 3,1 & 4 & Dobrá Voda \\
\hline 27.04.1992 & 48,44 & 17,22 & 2,3 & & Bratislav \\
\hline 14.07.1992 & 48,48 & 17,57 & 3,3 & 4 & Dobrá Voda \\
\hline 06.11 .1997 & 48,52 & 17,8 & 1,2 & & Jaslov. Bohunice \\
\hline 11.01 .1998 & 48,51 & 17,67 & 1,6 & & Jaslov. Bohunice \\
\hline 03.08.1998 & 48,53 & 17,67 & 0,5 & & Jaslov. Bohunice \\
\hline 05.05.1999 & 48,5 & 17,72 & 1,2 & & Jaslov. Bohunice \\
\hline 05.05.1999 & 48,49 & 17,73 & 2 & & Jaslov. Bohunice \\
\hline 18.10.1999 & 48,55 & 17,72 & 2 & & Chtelnica \\
\hline 19.10.1999 & 48,41 & 17,42 & 1,1 & & Dolne Ore \\
\hline 27.04 .2000 & 48,43 & 17,48 & 1,6 & & Boleráz \\
\hline 28.05.2000 & 48,53 & 17,44 & 1,9 & & Horná Krupá \\
\hline 28.05 .2000 & 48,53 & 17,44 & 0,5 & & Horná Krupá \\
\hline 08.08 .2000 & 48,5 & 17,54 & 1,5 & & Nahac \\
\hline 24.01 .2001 & 48,5 & 17,53 & 1,2 & & Nahac \\
\hline 06.06 .2001 & 48,65 & 17,79 & 1 & & Vrbové \\
\hline 28.06 .2001 & 48,61 & 17,8 & 1,2 & & Trebatice \\
\hline 15.12 .2002 & 48,52 & 17,47 & 1,8 & & Dobrá Voda \\
\hline 05.04 .2003 & 48,55 & 17,46 & 1,5 & & W Slovakia \\
\hline 17.06.2003 & 48,55 & 17,77 & 2 & & W Slovakia \\
\hline 19.09.2003 & 48,59 & 17,54 & 2,5 & 3 & W Slovakia \\
\hline
\end{tabular}

Tab. 4. Earthquakes within $13 \mathrm{~km}$ (white) and $26 \mathrm{~km}$ distance (grey) from the 1906 Dobrá Voda earthquake. The mainshock on 10.01 .1906 is highlighted. $I_{0}$ : Epicentral intensity (EMS98); M: magnitude estimated from I. Data source: ACORN catalogue (ACORN, 2004). Data marked with * from Shebalin and Leydecker (1998). 


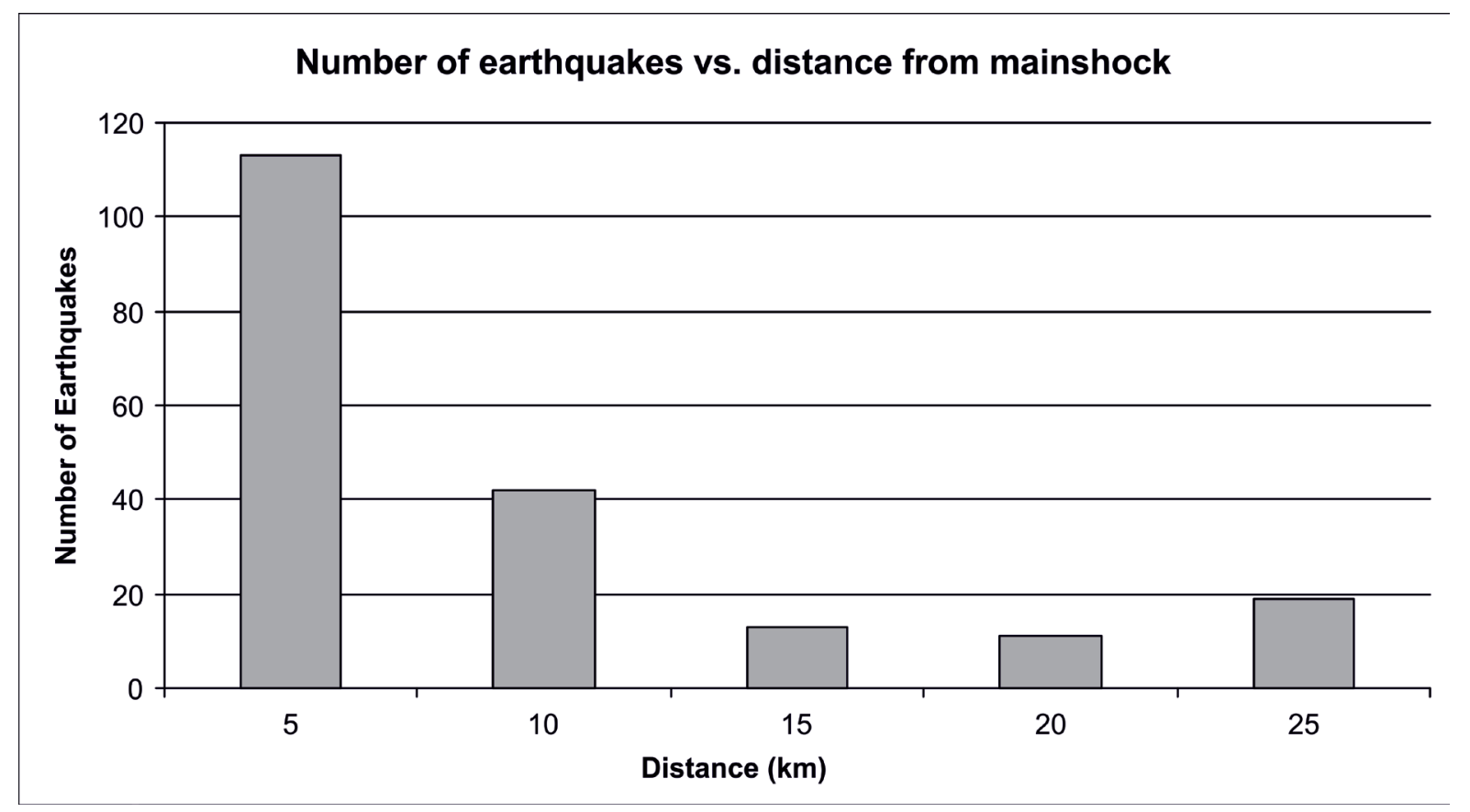

Fig. 4: Number of recorded earthquakes plotted versus epicentral distance from the 10.01.1906 Dobrá Voda mainshock (see Figure 3 for location).

distances up to $26 \mathrm{~km}$ from the Dobrá Voda mainshock (Fig. 5). In contrast, after the 1906 earthquake, the seismicity level significantly increased, especially within $13 \mathrm{~km}$ of epicentral distance. In total, 158 earthquakes were observed within $13 \mathrm{~km}$ from the mainshock and only 25 earthquakes in distances between $13 \mathrm{~km}$ and $26 \mathrm{~km}$. This concentration of seismicity close to the mainshock continues until the 1990s. This evolution can be interpreted as an ongoing aftershock sequence of the 1906 Dobrá Voda earthquake. The earthquakes outside the

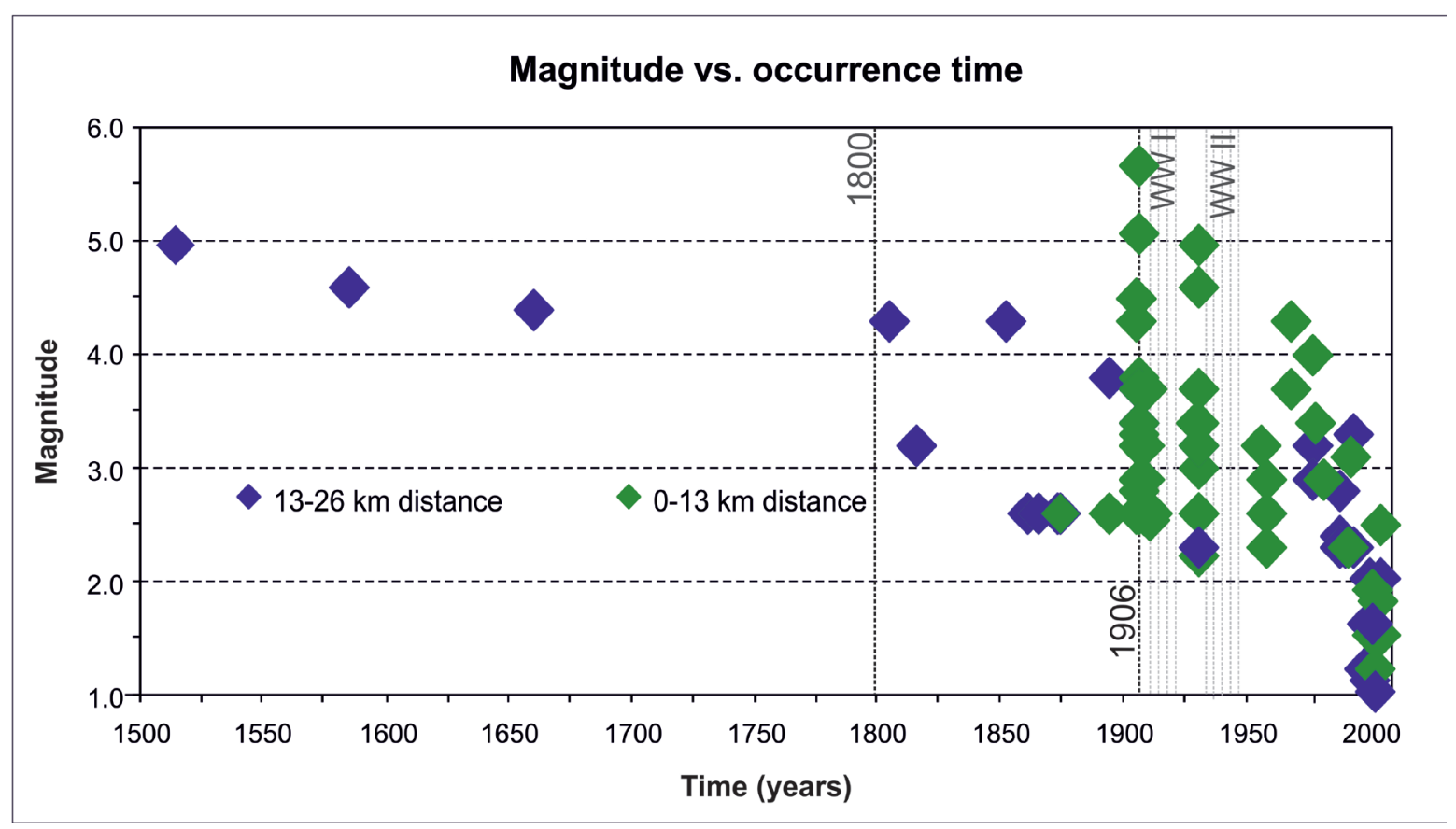

Fig. 5: Magnitude vs. occurrence time plotted for earthquakes in the vicinity of the Dobrá Voda earthquake. Blue diamonds show seismicity within 13-26 km distance, green diamonds within 0-13 km distance of the mainshock. Note the data gaps due to World War I (1914-1918) and World War II (1939-1945). 1800 indicates the onset of catalogue completeness for $\mathrm{I}_{0}<\mathrm{V}(\approx \mathrm{M}<3.5)$ is marked according to Nasir et al. (2013). 


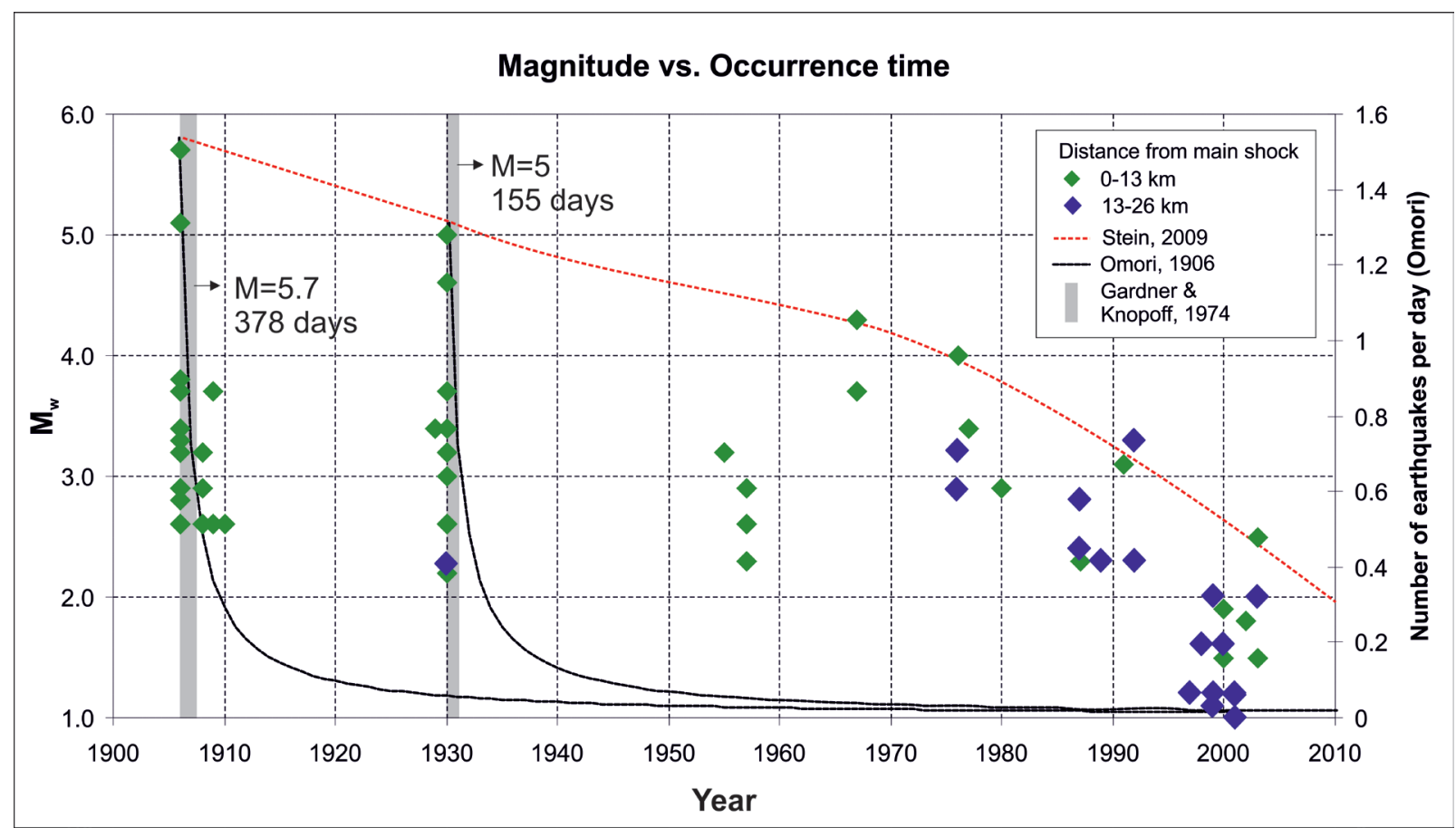

Fig. 6: Magnitude vs. time plot for earthquakes in the Dobrá Voda region between 1900 and 2004 . Blue diamonds show seismicity within $13-26 \mathrm{~km}$ distance, green diamonds within 0-13 km distance of the mainshock. The time series includes two major events: the 10.01.1906 (M=5.7) and 03.05.1930 $(M=5)$ earthquakes. Black lines show aftershock sequences expected from Omoris law, the red dotted line is the possible interpretation of a several-decades-long aftershock sequence following Stein and Liu (2009). The gray vertical lines indicate temporal windows following Gardener and Knopoff (1974), as interpolated from Tab. 3.

$13 \mathrm{~km}$ radius restart again around 1975. In general, the area experiences elevated seismicity until today.

In Fig. 6, earthquakes at the Dobrá Voda Segment are plotted for the time 1900-2004. The two major earthquakes in $1906(M=5.7)$ and $1930(M=5)$ are shown together with expected aftershock occurrences calculated from Omori's law (black lines in Fig. 6; Ogata, 1983) and the aftershock duration based on Gardner and Knopoff (1974) in Tab. 3. Using the values in Tab. 3, the latter method indicate 155 days of aftershocks for an earthquake of $M=5$ and 378 days for an earthquake of $M=5.7$ (grey lines in Fig. 6). Both time windows and the times of increased seismicity calculated from Omori's law are too short to cover the actual aftershock occurrences for the 1906 mainshock. Therefore, we discard the temporal windows as a suitable approach to define the aftershock sequence. Fig. 6 further indicates that Omori's law is suited to explain the aftershock occurrence for both major earthquakes. However, for the 1930 earthquake, we cannot be sure if the whole length of the aftershock sequence is recorded or if the aftershock sequence is cut short by an incomplete earthquake record. Therefore, the coincidence of data gaps due with war times (1914-18/1938-1945) and the recovery period afterwards may prevent a final conclusive interpretation of the aftershock sequences of the 1906 and 1930 events.

The temporal distribution of earthquakes within the $13 \mathrm{~km}$ radius around the 1906 earthquake show a long- term decay, which fits the model of Stein and Liu (2009) who proposed aftershock sequences extending over several decades to hundreds of years. Fig. 7 displays aftershock durations for selected events from three tectonic settings: plate boundary faults, broad plate boundary zones, and continental interiors (Stein and Liu, 2009). Despite the uncertainties in estimating both the duration and the rate at which tectonic slip loads the faults, the data indicate an inverse relationship between the aftershock durations and the slip rates. Faults at plate boundaries that are loaded by the rapid (typically faster than $10 \mathrm{~mm} / \mathrm{yr}$ ) plate motion show aftershock durations of about ten years. Faults within broad plate boundary zones but off the main boundaries move at only a small fraction of the plate motion (a few millimeters per year) and have longer aftershock durations (Stein and Liu, 2009). In diffuse plate boundary zones such as the North American Basin and Range, aftershock sequences often continue for fifty years or more. Considering the geological slip rate of 1-2 mm/yr for the Vienna Basin fault (Decker et al., 2005; Grenerczy et al., 2000; Grenerczy, 2002) and the ongoing elevated seismicity level in the Dobrá Voda region, the 1906 Dobrá Voda earthquake fits well into the data presented by Stein and Liu (2009). Therefore, the observed seismicity at the Dobrá Voda area might be still be influenced by the 1906 earthquake and could be interpreted as an extended aftershock sequence of almost 100 years duration. 


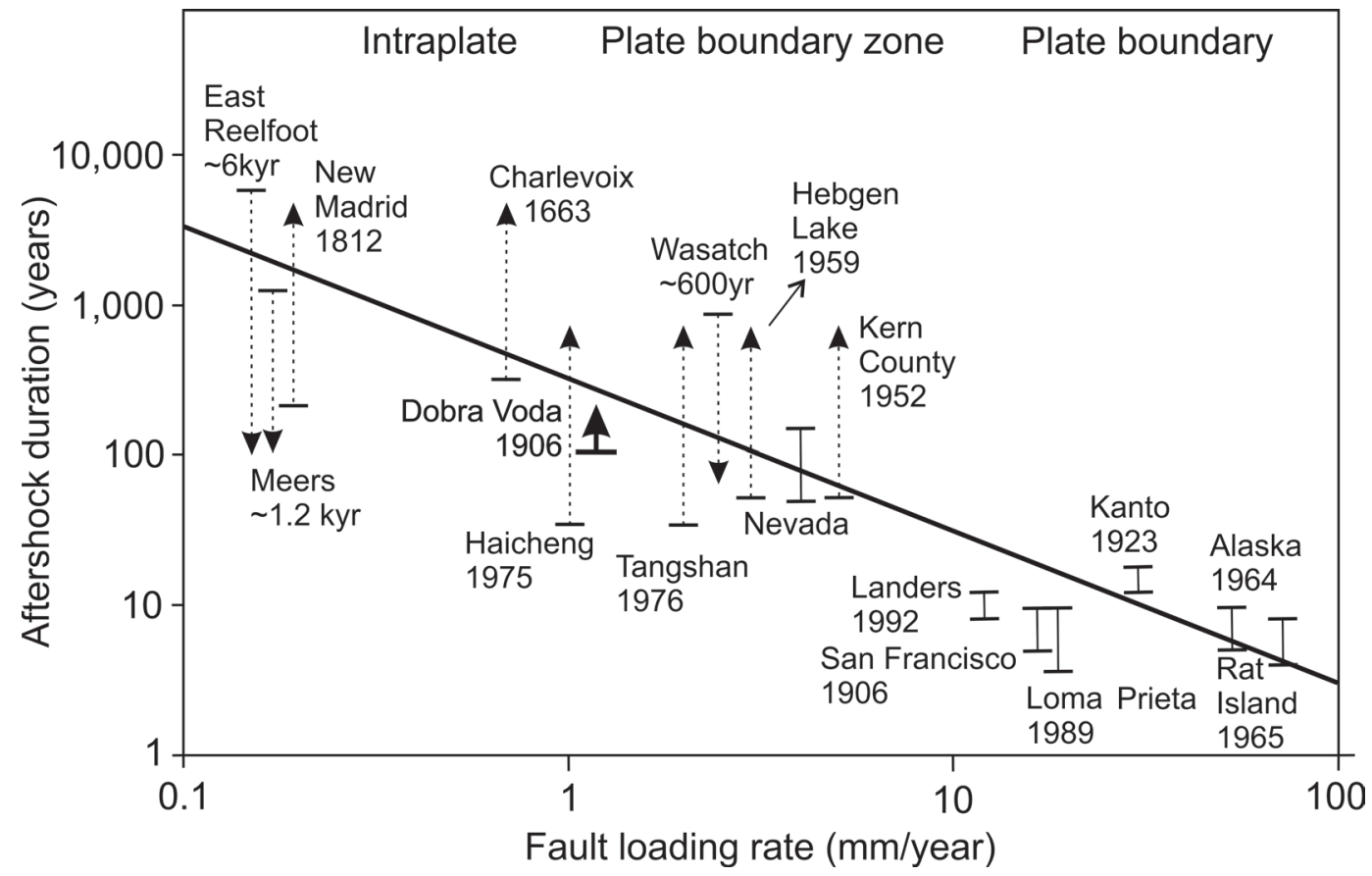

Fig. 7: Aftershock duration vs. fault loading rate for large earthquakes in different tectonic settings from Stein and Liu (2009). The solid line shows the model prediction. Aftershock durations have bars showing the span of published estimates. One-sided constraints have bars at the known value and arrows indicating the open value. For example, the New Madrid aftershocks span at least 200 years, but the upper bound is unconstrained. Similarly, the Wasatch aftershocks span less than 600 years, but the lower bound is unconstrained. Data and source for this plot obtained from the Supplementary Information of Stein and Liu (2009). The Dobrá Voda aftershock span is 100 years, but the upper bound is yet unconstrained. The graph shows that the Dobrá Voda aftershock sequence fits well to the model prediction for the slow (1-2 mm slip/yr) Vienna Basin strike-slip fault system, 1 kyr $=1000$ years.

\section{Conclusions}

The 1906 Dobrá Voda earthquake is the dominant earthquake at the northern part of the Vienna Basin Transfer Fault and has influenced the local seismic activity throughout the 20th century. Environmental effects of the earthquake described by contemporary authors include hydrological effects and mass movements with surface cracks, which help to constrain the epicentral intensity for the Dobrá Voda mainshock and its strongest aftershock in 1906. Applying the ESI 2007 intensity scale to these effects leads to an assessment of the related epicentral intensities with $\mathrm{I}_{0}=\mathrm{IX}$ and $\mathrm{I}_{0}=\mathrm{VIII}$, respectively. This new intensity estimates are regarded more appropriate to describe the maximum intensity of the events than the values listed in the ACORN and CENEC catalogues (ACORN, 2004; Grünthal et al., 2009).

Analysis of the temporal evolution of seismicity around Dobrá Voda reveals that significant earthquakes $(M=4-5)$ that occurred in the centuries prior to the mainshock are scattered over the entire region. After the 1906 Dobrá Voda mainshock, seismicity mainly concentrates within a distance of less than $13 \mathrm{~km}$ from the epicentre. This seismicity pattern persists for about 70 years.

The slow regular decline of seismicity after 1906, best shown by the gradual decrease of the largest observed magnitudes (Fig. 6), suggests that the aftershock sequence might have lasted longer than predicted by the Omori law and the level of background seismicity is only reached more than about 100 years after the mainshock. The observed seismicity pattern fits to the model of century-long aftershock sequences in intraplate regions as described by Stein and Liu (2009), suggesting that the slow loading rate of the VBTF can lead to aftershock sequences of severe earthquakes that exceed 100 years duration.

\section{Acknowledgements}

We thank Wolf Lenhardt for supporting us with data on the seismicity of the Vienna Basin and Erika Mühlmann for her work and translations from Hungarian language. We gratefully acknowledge the careful and very constructive reviews by Seth Stein and Christoph Grützner. Their comments and suggestions helped improving the manuscript considerably.

\section{References}

ACORN, 2004. Catalogue of Earthquakes in the Region of the Alps - Western Carpathians - Bohemian Massif for the period from 1267 to 2004. Computer File, Vienna (Central Institute for Meteorology and Geodynamics, Department of Geophysics Brno (Institute of Physics of the Earth, University Brno

Beidinger, A., Decker, K., 2011. 3D geometry and kinematics of the Lassee flower structure: Implication for segmentation and seismotectonics of the Vienna Basin strike-slip fault, Austria. Tectonophysics 499, 22-40. http://dx.doi.org/10.1016/j.tecto.2010.11.006.

Briestenský, M., Stemberk, J., Petro, L., 2007. Displacements registered around the 13 March 2006 Vrbové earthquake $M=3.2$ (Western Carpathians). Geol. Carpathica, 58/5, 487-493. 
Bus, Z., Grenerczy, G., Toth, L., Monus, P., 2009. Active crustal deformation in two seismogenic zones of the Pannonian region - GPS versus seismological observations. Tectonophysics, 474, 343-352.

Cancani, A., 1904. Sur l'emploi d'une double echelle sismique des intensitès, empirique et absolue. Gerlands Beiträge zur Geophysik, 2, 281-283.

Cipciar, A., Labák, P., Moczo, P., Kristeková, M., 2002. Monitoring of seismic phenomena by national seismic stations network. Publishing House D. Štúra, Bratislava, (in Slovak), $106,123-132$.

Csicskay, K., Cipciar, A., Fojtíková, L., Krsteková, M., Gális, M., Srbecký, M., Chovanová, Z., Bystrický, E., Kysel, R., 2018. The National Network of Seismic Stations of Slovakia Current state after 13 years of operation from the project of modernization and enhancement. Contributions to Geophysics and Geology, 48/4, 337-348.

Decker, K., Peresson, H., Hinsch, R., 2005. Active tectonics and Quaternary basin formation along the Vienna Basin Transform fault. Quaternary Science Reviews, 24, 307-322. Drimmel, J., Trapp, E., 1982. Earthquakes in Austria between 1971 and 1980. Sitzungsberichte-Österreichische Akademie der Wissenschaften, Mathematisch -Naturwissenschaftliche Klasse, Abteilung 1, 191, 73-102.

Fojtikova, L., Vavrycuk, V., Cipciar, A., Madaras, J., 2010. Focal mechanisms of micro-earthquakes in the Dobrá Voda seismoactive area in the Malé Karpaty Mts. Tectonophysics, 492(1-4), 213-229.

Gangl, G., Decker, K., 2011. Compilation of strong Austrian earthquakes with intensities higher than 7. Österreichische Ingenieur- und Architekten-Zeitschrift, 156, 229-237.

Gardner, J. K., Knopoff, L., 1974. Is the sequence of earthquakes in southern California, with aftershocks removed, poissonian?, Bulletin of the Seismological Society of America, 64/5, 1363-1367.

Grenerczy, G., Kenyeres, A., Fejes, I., 2000. Present crustal movement and strain distribution in Central Europe inferred from GPS measurements. Journal of Geophysical Research, 105 B9, 21, 835-846.

Grenerczy, G., 2002. Tectonic processes in the Eurasian-African plate boundary zone revealed by space geodesy. In: Stein, S., Freymueller J.T. (Eds.), Plate Boundary Zones. AGU Monograph Geodynamics Series, 30, 67-86.

Grünthal G. (Ed.), 1998. The European Macroseismic Scale (EMS-98). Cahiers du Centre Européen de Géodynamique et de Séismologie 15, pp. 99, (ECGS) Luxembourg.

Grünthal, G., Wahlström, R. and Stromeyer, D., 2009. The unified catalogue of earthquakes in central, northern, and north- western Europe (CENEC) - updated and expanded to the last millennium. Journal of Seismology, 13, 517-541.

Hammerl, Ch., Lenhardt, W., 2002. Historical Earthquakes in Styria/ Austria - Source Investigation - Revision of the Catalogue. Proc. of XXVIII ESC General Assembly, Genoa, Italy, 1-6 September 2002, 133.

Hammerl, Ch.,Lenhardt, W.A., 2013. Erdbeben in Niederösterreich von 1000 bis 2009 n. Chr. Abhandlungen der Geologischen Bundes-Anstalt, 67, 3-297.
Heidbach, O., Tingay, M., Barth, A., Reinecker, J., Kurfeß, D., Müller, B., 2008. The World Stress Map database release 2008. doi:10.1594/GFZ.WSM.Rel2008.

Hinsch, R., Decker, K., 2003. Do seismic slip deficits indicate an underestimated earthquake potential along the Vienna Basin Transfer Fault System? Terra Nova, 15, 343-349.

Hinsch, R., Decker, K., 2011. Seismic slip rates, potential subsurface rupture areas and seismic potential of the Vienna Basin Transfer Fault, International Journal of Earth Sciences, 100/8, 1925-1935.

Jarosinski, M., 1998. Contemporary stress field distortion in the Polish part of the western outer Carpathians and their basement. Tectonophysics, 297/1-4, 91-119.

Jarosinski, M., 2005. Ongoing tectonic reactivation of the Outer Carpathians and is impact on the foreland: Results of borehole breakout measurements in Poland. Tectonophysics, 410, 189-216.

Kadirioglu, F.T., Kartal, R.F., 2016. The new empirical magnitude conversion relations using an improved earthquake catalogue for Turkey and its near vicinity (1900-2012). Turkish J. Earth Sci., 25, 300-310.

Kárník, V., 1968. Seismicity of the European Area. Part 1. Academia, Praha.

Kováč, M., Bielik, M., Hók, J., Kováč, P., Kronome, B., Labák, P., Moczo, P., Plašienka, D., Šefara, J., Šujan, M., 2002. Seismic activity and neotectonic evolution of the Western Carpathians (Slovakia). EGU Stephan Mueller Special Publication Series, 3, 167-184.

Lenhardt, W.A., Švancara, J., Melichar, P., Pazdírková, J., Haviŕ, J., Sýkorová, Z., 2007. Seismic activity of the AlpineCarpathian-Bohemian Massif region with regard to geological and potential field data. Geol. Carpathica, 58/4, 397-412.

Marko, F., Fodor, L., Kováč, M., 1991. Miocene strike-slip faulting and block rotation in Brezovské Karpaty Mts. (Western Carpathians). Mineralia Slovaca, 23, 189- 200.

Michetti, A. M., Esposito, E. et al., Intensity Scale ESI 2007 in Mem. Descr. Carta Geologica d'Italia, Servizio Geologico d'Italia, APAT, Rome, Italy, 94

Michetti, A. M., Esposito, E. et al., 2004. The INQUA scale: An innovative approach for assessing earthquake intensities based on seismically-induced ground effects in natural environment. Special Paper Memorie Descrittive della Carta Geologica D'Italia, LXVII.

Mühlmann, E., Decker, K., Hintersberger, E. 2012. Neubewertung des Dobrá Voda Erdbebens an der Wiener Becken-Störung nach der Environmental Seismicity Intensity Scale (ESI) 2007. PANGEO Austria 2012, Abstracts, p.101, Universität Salzburg, 15-20 September 2012, Salzburg.

Müller, B., Zoback, M.L., Fuchs, K., Mastin, L., Gregersen, S., Pavoni, N., Stephansson, O., Ljunggren, C., 1992. Regional patterns of tectonic stress in Europe. J. Geophys. Res., 97/11, 783803.

Musson, R.M.W., Grünthal, G., Stucchi, M., 2010. The comparison of macroseismic intensity scales. J Seismology, 14, 413-428. 
Nasir, A., Lenhardt, W., Hintersberger, E., Decker, K., 2013. Assessing the completeness of historical and instrumental earthquake data in Austria and surrounding areas, Austrian Journal of Earth Sciences, 106/1, 90- 102. doi:10.14470/FX099882.

Ogata, Y., 1983. Estimation of the parameters in the modified Omori formula for the aftershock frequencies by the maximum likelihood procedure. J. Phys. Earth, 31, 115- 124.

Reinecker, J., 2000. Stress and deformation: Miocene to Present-day tectonics in the Eastern Alps. Tübinger Geowissenschaftliche Arbeiten, Reihe A, 55, 128pp.

Rethly, A., 1907. Erdbeben in Ungarn 1906 (in Hungarian with German abstracts). K. Ungar. Reichsanstalt für Meteorologie und Erdmagnetismums (Kir. Orsz. Meteorológiai és Földmágnességi Intézet), 109pp. (Budapest)

Scordilis, E.M., 2006. Empirical global relations converting $\mathrm{MS}$ and $\mathrm{mb}$ to moment magnitude. J. Seismology, 10: 225-236.
Šefara, J., Kováč, M., Plašienka, D., Šujan, M., 1998. Seismogenic zones in the Eastern Alpine - Western Carpathian Pannonian junction area. Geol. Carpathica, 49/4, 247-260. Stein, S., Liu, M., 2009. Long aftershock sequences within continents and implication for earthquake hazard assessment, Nature, 462/5, 87- 89.

Süss, F. E., 1897 . Das Erdbeben von Laibach am 14. April 1895. Jahrbuch der k.k. geologischen Reichsanstalt, 1897, 412-614.

Wells, D. L., Coppersmith, K. J., 1994. New empirical relationship among magnitude rupture length, rupture width, rupture area, and surface displacement. Bull. Seismol. Soc. Amer., 84, 974-1002.

Zsíros, T., 2005. Seismicity of the Western-Carpathians. Acta Geodaet. Geophys. Hungaria, 40/3-4, 455-467.

Received: 26.10 .2019

Accepted: 13.3.2020

Editorial handling: K. Stüwe 